\title{
Effects of dry period energy intake on insulin resistance, metabolic adaptation, and production responses in transition dairy cows on grass silage-based diets
}

\author{
S. Salin, ${ }^{* 1}$ A. Vanhatalo, ${ }^{*}$ S. Jaakkola, ${ }^{*}$ K. Elo, ${ }^{*}$ J. Taponen,† R. C. Boston, $\ddagger$ and T. Kokkonen ${ }^{*}$ \\ *Department of Agricultural Sciences, University of Helsinki, P.O. Box 28, FI-00014 Helsinki, Finland \\ †Department of Production Animal Medicine, University of Helsinki, Paroninkuja 20, FI-04920 Saarentaus, Finland \\ ¥New Bolton Center, University of Pennsylvania, Kennett Square 19348
}

\begin{abstract}
High energy intake in the dry period has reportedly had adverse effects on mobilization of body reserves, dry matter intake, and productivity of dairy cows. We investigated whether grass silage (GS) fed ad libitum (high energy intake, HEI; $141 \%$ of daily metabolizable energy requirements) in an 8-wk dry period affects metabolic adaptation - specifically, peripheral insulin resistance - compared with a total mixed ration consisting of GS, wheat straw, and rapeseed meal (55/40/5\%; controlled energy intake, CEI; $108 \%$ of metabolizable energy/d) fed ad libitum. Multiparous Ayrshire dairy cows $(\mathrm{n}=16)$ were used in a randomized complete block design until 8 wk after parturition. Commercial concentrates were fed 1 and $2 \mathrm{~kg} / \mathrm{d}$ during the last 10 to 6 and 5 to $0 \mathrm{~d}$ before the expected calving date, respectively. Postpartum, a similar lactation diet with ad libitum access to GS and increasing concentrate allowance (maximum of $16 \mathrm{~kg} / \mathrm{d}$ ) was offered to all. The HEI group gained more body weight and had higher plasma insulin, glucose, and $\beta$-hydroxybutyrate concentrations than the CEI group prepartum. Postpartal plasma glucose tended to be higher and milk yield was greater from wk 5 onward for HEI compared with CEI cows. An intravenous glucose tolerance test (IVGTT) was performed at $-13 \pm 5 \mathrm{~d}$ and $9 \pm 1 \mathrm{~d}$ relative to calving. The HEI cows had greater insulin response to glucose load and smaller area under the response curve for glucose than CEI cows in prepartal IVGTT. Thus, compensatory insulin secretion adapted to changes in insulin sensitivity of the peripheral tissues, preserving glucose tolerance of HEI cows. Higher insulin levels were needed in HEI cows than in CEI cows to elicit a similar decrement of nonesterified fatty acid concentration in prepartal IVGTT, suggesting reduced inhibition of lipolysis by insulin in HEI cows before parturition. In conclusion, high energy intake of moderately digest-
\end{abstract}

Received March 9, 2018.

Accepted August 13, 2018.

${ }^{1}$ Corresponding author: siru.salin@helsinki.fi ible GS with low concentrate feeding in the close-up dry period did not have adverse effects on metabolic adaptation, insulin sensitivity, and body mobilization after parturition. Instead, this feeding regimen was more beneficial to early-lactation performance than GS-based total mixed ration diluted with wheat straw. Key words: insulin resistance, transition dairy cow, energy intake, grass silage

\section{INTRODUCTION}

In loose-housing systems, group-fed dairy cows are prone to extra weight gain after drying-off. Dry cows easily overconsume energy relative to requirements, even when given moderate-energy maize silage-based diets (Janovick and Drackley, 2010). Although overfeeding may induce only minor visible changes in BCS, overfed cows share common metabolic features with the obese cow (Drackley et al., 2014). These include accretion of visceral fat depots, which drain directly to the liver, predisposing cows to health problems (Roche et al., 2013; Drackley and Cardoso, 2014), and decreased DMI in early lactation (Agenäs et al., 2003; Dann et al., 2006; Janovick and Drackley, 2010).

The daily energy intake of dry cows offered feed ad libitum can be controlled by feeding bulky forages rich in fiber, such as wheat straw (WS). Restricting energy allowance by diluting maize silage-based diets with WS during the dry period improved DMI and energy balance (EB) and decreased hepatic lipid content and adipose tissue (AT) mobilization in very early lactation (Janovick and Drackley 2010; Janovick et al., 2011; Mann et al., 2015). This suggests that restriction of energy intake in the dry period improves metabolic balance in early lactation despite higher nonesterified fatty acid (NEFA) levels in the transition period (Douglas et al., 2006; Loor et al., 2006; Roche et al., 2015). However, the results have been more equivocal in dry cows on grass silage (GS)-based feeding strategies. No beneficial effects on DMI and lipid mobilization were reported when dilution of GS or mixture of 
grass and maize silage with straw was compared with pure GS (Ryan et al., 2003; Butler et al., 2011) or when the allowance of GS was restricted to meet the energy requirements (T. Kokkonen, S. Salin, S. Jaakkola, J. Taponen, K. Elo, and A. Vanhatalo, unpublished data).

Some recent studies have shown that prepartal energy intake with or without BCS changes may affect maternal insulin resistance (IR) during the periparturient period (Zachut et al., 2013; De Koster et al., 2015; Salin et al., 2017). The hyperbolic relationship between insulin secretion and insulin sensitivity suggests that any environmental change in insulin sensitivity (e.g., in response to obesity) will be compensated by an increase in insulin secretion in response to glucose (Bergman, 1989; Kahn et al., 1993). This hyperbolic relationship in insulin dynamics, well established in human studies, was also recently verified in transition dairy cows (Salin et al., 2017). As a result of prepartal overfeeding, the AT may be more refractory to the actions of insulin (Salin et al., 2017), and cows prone to lose great amounts of BW in the transition period may be more resistant to insulin's effect on lipolysis inhibition than cows with moderate BW loss (Zachut et al., 2013). However, other recent research found minor effects of increased body fatness and high energy intake on inhibition of lipolysis by insulin and insulin signaling in AT of transition dairy cows (De Koster et al., 2016b; Mann et al., 2016; Jaakson et al., 2018). Instead, overconditioned cows were more insulin resistant in regard to glucose metabolism and glucose transport into AT in late pregnancy than leaner cows (De Koster et al., 2015; Jaakson et al., 2018).

In our previous experiment (Salin et al., 2017; T. Kokkonen, S. Salin, S. Jaakkola, J. Taponen, K. Elo, and A. Vanhatalo, unpublished data), we showed that high energy intake of GS induced a more refractory NEFA response during the prepartal IVGTT when compared with cows fed controlled amount of GS to meet ME requirements, whereas a more pronounced NEFA response was observed in overfed cows after parturition. However, a relatively short dry period of $6 \mathrm{wk}$ and a feeding practice where energy oversupply was gradually restricted during the close-up dry period might have contributed to the absence of differences in accretion and mobilization of body reserves between high- and controlled-energy diets. This may have dampened the metabolic and hormonal effects in the former study. Accordingly, we did not observe effects on glucose and insulin responses during the transition period.

The main objective of this experiment was to determine whether increased dietary energy level by ad libitum allowance of GS during an 8-wk dry period and subsequent putative increase of body condition during an 8-wk dry period deteriorates pregnancy-induced IR followed by abnormal metabolic regulation during the transition period. Our hypothesis was that high dietary energy intake accelerates accretion and mobilization of body reserves, affects hormonal control of metabolism, decelerates the increase of DMI in early lactation, and thus affects production responses during the first $8 \mathrm{wk}$ of lactation. We also assumed that limiting DMI by increasing the NDF content of GS-based diet with adding of WS to TMR would prevent the aforementioned negative effects.

\section{MATERIALS AND METHODS}

\section{Cows, Diets, and Experimental Design}

The experimental procedures were conducted under the protocols approved by the National Animal Ethics Committee in Finland (Hämeenlinna). The study was conducted with 16 Finnish multiparous Ayrshire cows using a randomized complete block design. Experimental animals were dried off either before $(\mathrm{n}=$ 12 ; average $=12.6 \mathrm{~d}$; median $=6.0 \mathrm{~d}$ ) or on the day of $(\mathrm{n}=4)$ the initiation of the experimental period. Those that were dried off in advance were fed refusals of GS until 8 wk before expected parturition. The cows were paired according to expected calving date, parity (second through sixth), BW $(733 \pm 115.1 \mathrm{~kg}$; mean \pm $\mathrm{SD})$, and BCS $(3.5 \pm 0.54$; mean $\pm \mathrm{SD})$. The $305-\mathrm{d}$ milk yield from the previous lactation of the cows was $10,280 \pm 1,469 \mathrm{~kg}$ (mean $\pm \mathrm{SD}$ ). Within pairs, cows were allocated to 1 of the 2 prepartal dietary treatments 8 wk before the expected parturition $(57 \pm 5 \mathrm{~d}$ before the actual calving day; mean $\pm \mathrm{SD}$ ). The dietary treatments were (1) ad libitum access to TMR containing a mixture of first-cut wilted GS (55\%, digestible $\mathrm{OM}=667 \mathrm{~g} / \mathrm{kg}$ of $\mathrm{DM})$, WS $(40 \%$, digestible $\mathrm{OM}=$ $457 \mathrm{~g} / \mathrm{kg}$ of $\mathrm{DM}$ ), and rapeseed meal (5\%, digestible $\mathrm{OM}=700 \mathrm{~g} / \mathrm{kg}$ of DM) contributing to an average of $587 \mathrm{~g} / \mathrm{kg}$ of digestible $\mathrm{OM}$ and an ME content of 9.1 MJ of ME $/ \mathrm{kg}$ of DM (controlled energy intake; CEI) and (2) ad libitum access to second-cut wilted GS (high energy intake; HEI), containing $638 \mathrm{~g} / \mathrm{kg}$ of DM of digestible $\mathrm{OM}$ and an ME content of $10.1 \mathrm{MJ}$. The silage was ensiled in round bales. Prior to baling, a formic acid-based additive (AIV2 Plus, Kemira Ltd., Helsinki, Finland) was applied at a rate of $7.4 \mathrm{~L} /$ tonne. The preparation of TMR is described in detail in Selim et al. (2015). Grass silage or TMR was offered to cows 3 times daily at 0700,1300 , and $2000 \mathrm{~h}$. The composition of feeds is presented in Table 1.

Both diets were supplemented with $1 \mathrm{~kg} / \mathrm{d}$ of commercial concentrate (Pro-Maituri 20, Raisioagro Ltd., Raisio, Finland) during d 10 to d 6 before the expected calving date and with $2 \mathrm{~kg} / \mathrm{d}$ thereafter until the day of 
Table 1. Chemical composition and calculated energy content of forages and concentrates in dietary treatments $\mathrm{CEI}^{1}$ and $\mathrm{HEI}^{2}$

\begin{tabular}{|c|c|c|c|c|c|c|c|c|}
\hline $\begin{array}{l}\text { Item, } \mathrm{g} / \mathrm{kg} \text { of } \mathrm{DM} \\
\text { unless noted }\end{array}$ & \multicolumn{4}{|c|}{ CEI } & $\begin{array}{c}\text { HEI } \\
\begin{array}{c}\text { Grass } \\
\text { silage }^{9}\end{array}\end{array}$ & $\begin{array}{c}\text { Lactation } \\
\begin{array}{c}\text { Grass } \\
\text { silage }\end{array}\end{array}$ & Concentrate $^{3}$ & $\begin{array}{l}\text { Protein } \\
\text { supplement }\end{array}$ \\
\hline Ash & 60 & 63 & 74 & 68 & 84 & 85 & 69 & 83 \\
\hline $\mathrm{CP}$ & 122 & 146 & 48 & 368 & 129 & 146 & 196 & 288 \\
\hline Ether extract & - & - & - & 57 & - & - & 50 & 78 \\
\hline $\mathrm{D}$-value ${ }^{13}$ & 587 & 668 & 457 & - & 638 & 687 & - & - \\
\hline $\mathrm{MP}$ & - & 80.5 & 42.0 & $169^{11}$ & 62.4 & 67.3 & $119^{12}$ & $140^{12}$ \\
\hline
\end{tabular}

${ }^{1} \mathrm{CEI}=$ controlled energy intake during the 8 -wk dry period providing $108 \%$ of ME requirements/d.

${ }^{2} \mathrm{HEI}=$ ad libitum energy intake during the 8 -wk dry period providing $141 \%$ of ME requirements/d.

${ }^{3}$ Concentrate fed during the last $12 \pm 5 \mathrm{~d}$ (mean $\pm \mathrm{SD}$ ) of pregnancy and during lactation.

${ }^{4}$ Protein supplement fed during lactation.

${ }^{5}$ Total mixed ration fed to CEI during the dry period.

${ }^{6}$ Grass silage in TMR fed to CEI during the dry period. Mean fermentation characteristics: pH 3.9; lactic acid 3.8\% in DM; acetic acid 1.5\% in DM; butyric acid $0.034 \%$ in DM; propionic acid $0.14 \%$ in DM; sugars $6.7 \%$ in DM; ammonium-N $6.7 \%$ of total N; soluble $\mathrm{N} 62 \%$ of total N.

${ }^{7}$ Wheat straw in TMR fed to CEI during the dry period.

${ }^{8}$ Rapeseed meal in TMR fed to CEI during the dry period.

${ }^{9}$ Grass silage fed to HEI during the dry period. Mean fermentation characteristics: $\mathrm{pH} 4.1$; lactic acid 3.3\% in DM; acetic acid 0.70\% in DM; butyric acid $0.00 \%$ in DM; propionic acid $0.12 \%$ in DM; sugars $1.6 \%$ in DM; ammonium-N $5.5 \%$ of total N; soluble N $47 \%$ of total N.

${ }^{10}$ Grass silage fed during lactation. Mean fermentation characteristics: pH 4.4; lactic acid 3.3\% in DM; acetic acid 1.4\% in DM; butyric acid $0.20 \%$ in DM; propionic acid $0.12 \%$ in DM; sugars 1.1\% in DM; ammonium-N $6.8 \%$ of total N; soluble N $61 \%$ of total N.

${ }^{11}$ Values adopted from Luke (2017).

${ }^{12}$ Values provided by the manufacturer (Raisio Oy Ltd., Raisio, Finland).

${ }^{13}$ In vitro digestible $\mathrm{OM}$ in DM.

calving. The chemical composition of the concentrates is shown in Table 1. The concentrate ration was fed twice daily (at 0615 and $1700 \mathrm{~h}$ ). A commercial mineral and vitamin supplement (Tunnu-Melli, Raisioagro Ltd.) was top dressed $(0.2 \mathrm{~kg} / \mathrm{d})$ once daily on forage during the dry period (Supplemental Table S1; https: //doi.org/10.3168/jds.2018-14728). After calving, all cows were offered wilted GS (average D-value $=687$ $\mathrm{g} / \mathrm{kg}$ of DM) ad libitum. The silage was cut and mixed in a stationary mixer and distributed 4 times per day (at $0500,1100,1500$, and $2000 \mathrm{~h}$ ) by a rail-suspended distribution wagon (Pellon Group, Ylihärmä, Finland). The cows were fed an increasing amount of the same commercial concentrate as before calving and a protein and mineral plus vitamin supplement (Amino-Maituri 30, Pihatto-Melli, Raisioagro Ltd.; Supplemental Table S18). The rate of increase in daily concentrate ration was similar for all cows (Supplemental Table S2; https: //doi.org/10.3168/jds.2018-14728). The amount of concentrate was $8 \mathrm{~kg} / \mathrm{d}$ by the end of lactation wk 1 ( 7 $\mathrm{kg} / \mathrm{d}$ of cereal concentrate $+1 \mathrm{~kg} / \mathrm{d}$ of protein supplement); the maximum amount of $16 \mathrm{~kg} / \mathrm{d}(12.5 \mathrm{~kg} / \mathrm{d}$ of cereal concentrate $+3.5 \mathrm{~kg} / \mathrm{d}$ of protein supplement) was achieved by lactation d 32. During the first week of lactation, the daily concentrate ration was fed 4 times per day (at 0615, 1000, 1645, and $1930 \mathrm{~h}$ ) to separate feeding troughs.

The experimental animals were housed in tiestalls with sawdust bedding and rubber mats throughout the dry period. The cows had continuous access to automatic water troughs and salt licks. Approximately $1 \mathrm{wk}$ before the expected calving, the cows were moved to individual calving pens. The cows were returned to the tiestalls 2 to $5 \mathrm{~d}$ after parturition. The tiestalls and the calving pens were equipped with forage intake control feeding stations (Insentec BV, Marknesse, the Netherlands), which were fitted with separate concentrate troughs. The cows were kept in tiestalls until d 10 of lactation and moved to a freestall barn equipped with a roughage intake control system (Insentec BV) with separate automatic concentrate feeders (Lely Cosmix, Lely Industries N.V., Maassluis, the Netherlands).

\section{Feed and Milk Samples, Chemical Analysis, and Measurements}

Feed offered and feed refused (silage and concentrates) were recorded daily. The feeds were sampled weekly, and the cereal concentrate and silage samples were pooled to form a monthly sample. Samples of 
concentrates were pooled to form a 2-mo sample. Feed samples were analyzed as described by Salin et al. (2012), and DM content of silages was corrected for the loss of volatiles according to Huida et al. (1986). The VFA of the silage was determined by liquid chromatographic analysis using a Waters Acquity UPLC chromatography apparatus (Waters, Milford, MA) as described in detail by Puhakka et al. (2016). Total fat of concentrates was analyzed with ether extraction and hydrolysis with $\mathrm{HCl}$ (SoxCap 2047 Hydrolysis Unit; Foss Soxtec 8000, Foss Analytical, Hillerød, Denmark). During the first week of lactation, the cows were milked twice daily at 0630 and $1700 \mathrm{~h}$, and thereafter until lactation wk 8 the cows were milked with an automated milking system (Lely Astronaut A3, Lely Industries N.V.). The milk yield was recorded for every milking. The milk samples were collected on 4 consecutive milkings at 1, 2, 4, 6, and 8 wk after parturition, mixed with preservative (bronopol, Valio Ltd., Seinäjoki, Finland), and sent to a commercial laboratory (Valio Ltd.) for analysis of fat, protein, lactose, and urea (MilkoScan 133B analyzer; Foss Electric A/S, Hillerød, Denmark).

The cows were weighed on 2 consecutive days at 8,6 , 4,2 , and 1 wk before the expected calving day; on $\mathrm{d} 1$ and 2 postpartum; and at 1, 2, 4, 6, and 8 wk after calving. The cows were always weighed at the same time of day, starting at $1300 \mathrm{~h}$, to minimize the influence of milking and feeding. In the case of postdate pregnancies, additional weighing was done on alternate days until the due date. Body condition score (Edmonson et al., 1989) was recorded by the same person throughout the experiment at the same time points as weighing. The cross-section of the longissimus dorsi muscle (pars lumbalis) and subcutaneous fat thickness were measured on the right transversal process of the third lumbar vertebra, 2 to $3 \mathrm{~cm}$ medially from the lateral end at $14 \mathrm{~d}$ before and 1, 7, and $28 \mathrm{~d}$ after parturition using an Aloka SSD-500 ultrasound scanner (Aloka, Tokyo, Japan) with a $5.0-\mathrm{MHz}$ transducer after shaving of the positions.

\section{Blood Samples and Intravenous Glucose Tolerance Tests}

Blood sampling was performed by puncture of the coccygeal blood vessels at 56, 42, 28, 21, 16, 12, 7, 5, 3, and $1 \mathrm{~d}$ before the expected calving date and at $1,3,5$, $7,14,21,28,42$, and $56 \mathrm{~d}$ after calving. The samples were collected into evacuated collection tubes (Vacutainer; BD Medical, Franklin Lakes, NJ) containing potassium EDTA and placed on ice. Blood samples were centrifuged at $2,220 \times g$ for $10 \mathrm{~min}$ at $20^{\circ} \mathrm{C}$ to separate plasma, which was then stored at $-20^{\circ} \mathrm{C}$ for analyses of glucose, insulin, glucagon, BHB, NEFA, and glycerol.
Plasma samples for 3-methylhistidine (3-MH) were collected at $12 \mathrm{~d}$ before the expected calving and at 1 , 7 , and $28 \mathrm{~d}$ after parturition and handled as described above. The samples were precipitated with $10 \%$ sulfosalicylic acid and analyzed by ultra performance liquid chromatography (Acquity UPLC, Waters) equipped with a BEH C18 column $(100 \mathrm{~mm} \times 2.1 \mathrm{~mm})$ according to the manufacturer's instructions. Plasma glycerol was analyzed with a direct colorimetric method (Foster et al., 1978) using a commercially available kit (GY105, Randox Laboratories Ltd., Crumlin, UK). Plasma glucose, NEFA, and insulin were analyzed as described by Salin et al. (2012), plasma BHB and glucagon as described by Selim et al. (2014), and plasma 3-MH as in Lamminen et al. (2017). Intra-assay and interassay coefficients of variation for plasma metabolites and hormones, liver TG and total lipids, hepatic and AT gene expression of enzymes involved in the gluconeogenesis, and fatty acid metabolism were reported by Selim et al. (2015).

Intravenous glucose tolerance tests (IVGTT) were performed $13 \pm 5 \mathrm{~d}$ before the actual delivery date and $9 \pm 1 \mathrm{~d}$ postpartum at $0900 \mathrm{~h}$ as described in detail by Salin et al. (2012). Briefly, on the previous day, sterile indwelling catheters (left: Mila 14G, Mila International, Florence, KY; right: homemade catheter made of silicone tubing) were inserted into jugular veins and sutured to the skin (Vetafil Bengen, Hannover, Germany), and a 25-cm polyvinyl chloride elongation tube (Connecta, BD Medical) was connected to the catheters. The left catheter was used for glucose infusion, and the right one was used for collection of blood samples. Infusion of $0.25 \mathrm{~g}$ of glucose $/ \mathrm{kg}$ of BW (glucose $300 \mathrm{mg} / \mathrm{mL}$; B. Braun Melsungen AG, Melsungen, Germany) was performed over $4.5 \pm 1.4 \mathrm{~min}$ and $4.6 \pm 2.3 \mathrm{~min}$ (mean \pm SD) pre- and postpartum, respectively, with an average infusion rate of $151 \pm 39 \mathrm{~mL}$ of glucose solution/min. Blood samples were collected via catheters at $-10,-5$, $0,1,2,3,4,5,6,7,8,10,12,14,16,18,20,22,24,26$, $28,30,40,50,60,70,80,90,120,150,180,210$, and 240 min relative to the initiation of glucose infusion. The samples were handled as described above. Feed but not water was withheld $2 \mathrm{~h}$ before and during the IVGTT.

\section{Calculations and Statistical Analyses}

One cow from the CEI group was excluded from the trial 4 wk after parturition due to presumed abomasal problems. The data for $1 \mathrm{cow}$ in the HEI group was omitted from the statistical calculations for the first 2 wk of the dry period due to error in treatment allocation. One cow in the CEI treatment displayed abnormal NEFA response to glucose bolus prepartum; hence, the data set of the particular animal was considered an out- 
lier and excluded from the analysis of NEFA dynamics during the IVGTT at $13 \mathrm{~d}$ before parturition.

The ME concentration of the forages was calculated based on the digestible OM concentration in DM (Dvalue), and the ME concentration of concentrates was calculated based on the feed tables (Luke, 2017). The $\mathrm{EB}$ was calculated as the difference between the ME intake and the ME requirements (Luke, 2017). A correction equation for associative effects of feeds and feeding level was used when ME intake was calculated (Luke, 2017). The ECM was calculated according to Sjaunja et al. (1991).

The net incremental area under the response curve (AUC) for plasma glucose, insulin, and NEFA during the first 60 and $240 \mathrm{~min}$ of IVGTT was calculated as described by Salin et al. (2017). The decrement of NEFA was calculated by subtracting the nadir concentration from the basal NEFA concentration. Clearance rate $(\% / \mathrm{min})$ of metabolites and insulin was calculated using PROC NLIN of SAS version 9.3 (SAS Institute Inc., Cary, NC) as described previously (Pires et al., 2007; Salin et al., 2012). For each IVGTT, the minimal model (MM; Bergman, 1989) was applied to glucose and insulin curves using a commercial software (MinMod Millenium, Minmod Inc., Pasadena, CA) with methods described previously (Boston et al., 2003; Salin et al., 2012). Briefly, the model provides values for insulin sensitivity $\left(\mathbf{S I} ; \times 10^{-4} \mathrm{~min}^{-1} / \mu \mathrm{IU}\right.$ per milliliter), defined as the fractional rate of glucose uptake per unit of plasma insulin; glucose effectiveness $(\mathbf{S g}$; $\mathrm{min}^{-1}$ ), which characterizes non-insulin-mediated glucose disposal; acute insulin response to glucose $\left(\mathbf{A I R}_{\mathbf{G}}\right.$; $\mu \mathrm{IU} / \mathrm{mL}$ per minute), which represents the endogenous insulin response to a glucose bolus; and disposition index (DI), a measure of overall glucose tolerance and insulin responsiveness corrected for changes in SI. The DI is calculated as the product of SI and $\mathrm{AIR}_{\mathrm{G}}$. For the evaluation of the NEFA dynamics during the IVGTT, a NEFA model was used (Boston and Moate, 2008).

Data for feed intake, milk production, blood hormone and metabolite concentrations, BW, BCS, EB, and postpartal plasma 3-MH and back muscle diameter were analyzed as repeated-measures ANOVA using the MIXED procedure of SAS version 9.3 (SAS Institute Inc.). Prepartum and postpartum data were analyzed separately. Measurements of DMI, EB, and milk production were reduced to weekly means before statistical analysis. Three covariance structures were tested for each variable analyzed: compound symmetry, unstructured, and autoregressive order 1. For unequally spaced measures, spatial power was used instead of autoregressive order 1 . The statistical model included fixed effects of treatment, time (day or week relative to calving), and the interaction between treatment and time (diet $\times$ time) and a random effect of block and interaction between block and time. Degrees of freedom were estimated by using the Kenward-Roger option in the model statement. The covariance structure that resulted in the smallest Schwarz Bayesian information criterion was used.

The data of BW, BCS, and $\mathrm{EB}$ at particular time points and their changes and prepartal plasma 3-MH and back muscle diameter, as well as data derived from IVGTT were analyzed by ANOVA with a model including the fixed effect of treatment and the random effect of block using the MIXED procedure of SAS (version 9.3; SAS Institute Inc.). A fixed effect of interval between the sampling day and the actual day of parturition was included in the statistical model of the prepartal IVGTT data.

Prior to statistical analysis, residuals of each variable were checked for normality using the MIXED and UNIVARIATE procedures of SAS. To correct for the deviations from normality and homoscedasticity of the residuals for the data of each variable, the variables were subjected to reciprocal or log-transformation when needed. Friedman's nonparametric test was used whenever the above-mentioned normalization processes were not effective, as was the case in the MMderived prepartal estimates SI and Sg. All values in the tables and figures are reported as least squares means and standard error of the mean. Back-transformed least squares means and standard error of the mean are reported from the analysis of transformed data. The relationships between plasma concentrations and calculated parameters describing insulin sensitivity during IVGTT were investigated by Spearman's correlation analysis using the CORR procedure of SAS. The effects were considered statistically significant at $P<0.05$, and trends for effects are discussed at 0.05 $\leq P<0.10$.

\section{RESULTS}

\section{Diets and Intakes}

The analyzed composition of prepartum and postpartum diets is shown in Table 1. The formulation of TMR was successful, and the targeted difference in the NDF content of the diets between HEI and CEI was achieved. The average NDF content of the GS of HEI was lower than the NDF levels measured from the preliminary samples, leading to an average NDF difference of 120 $\mathrm{g} / \mathrm{kg}$ of DM between the treatments. The inclusion of rapeseed meal in the TMR was successful in balancing the $\mathrm{CP}$ content of CEI close to the $\mathrm{CP}$ content of GS fed in HEI. The digestible OM content (D-value) of the CEI was, as expected, lower than that of HEI. 
The experimental design led to expected significant differences in DMI and intakes of other nutrients as well as differences in ME intakes between the treatments during the prepartum period (Table 2). The total DM and forage DM intake (Figure 1) of HEI were 2.2 and $2.9 \mathrm{~kg} / \mathrm{d}$ higher, respectively, in HEI cows than in CEI cows during the dry period $(P<0.01)$. The DMI expressed as percentage of $\mathrm{BW}$ tended to be greater during the entire dry period in HEI cows than in CEI cows $(P=0.05)$, and the significant diet $\times$ time interaction showed that the difference in DMI was largest on wk -8 and -6 relative to parturition, averaging 2.0 and $1.5 \%$ of BW, respectively ( $\mathrm{SEM}=0.12 ; P=0.04)$. The EB during the dry period (Figure 2) was approximately $30 \%$ greater in HEI cows than in CEI cows $(P<0.001)$, and the average energy intake was 141 and 108\% (SEM $=5.46 ; P<0.001$ ) of the requirements (Luke, 2017) in HEI and CEI cows, respectively. After parturition, the dry period feeding had no effect on total DMI and intake of nutrients except for a significant difference in concentrate DMI. The HEI cows had higher intake of concentrates than the CEI cows from wk 4 onward (diet $\times$ time, $P=0.05$ ), resulting in $0.4 \mathrm{~kg} / \mathrm{d}$ greater postpartal average DMI of concentrates in HEI cows than in CEI cows (SEM $=0.09 ; P=0.003)$. The EB was not affected by the prepartal dietary treatment after parturition $(P=0.46)$.

\section{Body Reserves}

The cows were dry for an average of $67 \pm 11.1 \mathrm{~d}$ (mean $\pm \mathrm{SD}$ ). The parameters describing the changes of body reserves are shown in Table 3. The initial BW and BCS were not different between treatments by design. However, the significant diet $x$ time interactions in BW $(P=0.005)$ and BCS $(P=0.02)$ during the dry period indicated a steeper increment of BW and BCS in HEI cows than in CEI cows (Supplemental Figures S1 and S2; https://doi.org/10.3168/jds.2018-14728). The BW change from $\mathrm{d}-56$ to $\mathrm{d}-5$ before parturition was greater in HEI cows than in CEI cows $(P=0.03)$ and accounted for a total increment of 75.0 versus 40.8 $\mathrm{kg}(\mathrm{SEM}=9.1)$, respectively. The BCS change tended to be greater in HEI cows than in CEI cows prepartum and increased in total 0.37 versus $0.14(\mathrm{SEM}=0.08$; $P=0.07$ ), respectively, from $\mathrm{d}-56$ to $\mathrm{d}-5$. The birth weights of calves did not differ between the treatments. We found no treatment and no diet $\times$ time interaction effects on BW, BCS, or changes in these parameters during early lactation. Back muscle diameter on $-14 \mathrm{~d}$ prepartum was similar in both groups but declined to a smaller average value in CEI cows compared with HEI cows during the first $4 \mathrm{wk}$ of lactation $(P=0.01)$. We observed no differences in back fat thickness.

\section{Plasma Metabolites and Hormone Concentrations}

Basal plasma hormone and metabolite concentrations are depicted in Table 4. The concentration of plasma glucose before parturition was higher in HEI cows than in CEI cows, and the difference was most evident during the last 2 wk of pregnancy (diet $\times$ time, $P=0.06$; Figure 3). After parturition, the HEI cows tended to have higher glucose concentrations than the CEI cows

Table 2. Effect of dry period energy intake and diet composition on DMI and energy balance

\begin{tabular}{|c|c|c|c|c|c|}
\hline \multirow[b]{2}{*}{ Item } & \multirow[b]{2}{*}{$\mathrm{CEI}^{1}$} & \multirow[b]{2}{*}{$\mathrm{HEI}^{2}$} & \multirow[b]{2}{*}{ SEM } & \multicolumn{2}{|c|}{$P$-value } \\
\hline & & & & Diet & Diet $\times$ time \\
\hline \multicolumn{6}{|l|}{ Prepartum } \\
\hline Forage DM, kg/d & 10.8 & 13.7 & 0.46 & $<0.001$ & 0.74 \\
\hline Concentrate $\mathrm{DM},{ }^{3} \mathrm{~kg} / \mathrm{d}$ & 1.3 & 1.4 & 0.10 & 0.77 & 0.03 \\
\hline Total DM, kg/d & 12.0 & 14.2 & 0.50 & 0.002 & 0.64 \\
\hline DMI, \% of BW & 1.58 & 1.86 & 0.10 & 0.05 & 0.04 \\
\hline $\mathrm{NDF}, \mathrm{kg} / \mathrm{d}$ & 7.5 & 7.3 & 0.3 & 0.70 & 0.29 \\
\hline MP, kg/d & 0.86 & 0.89 & 0.03 & 0.41 & 0.54 \\
\hline $\mathrm{ME}, \mathrm{MJ} / \mathrm{d}$ & 109 & 144 & 4.8 & $<0.001$ & 0.52 \\
\hline ME balance, MJ/d & 8.52 & 39.4 & 4.97 & 0.004 & 0.51 \\
\hline \multicolumn{6}{|l|}{ Postpartum } \\
\hline Silage DM, kg/d & 11.2 & 11.3 & 0.54 & 0.88 & 0.82 \\
\hline Concentrate DM, kg/d & 10.9 & 11.3 & 0.09 & 0.003 & 0.05 \\
\hline Total DM, kg/d & 22.1 & 22.6 & 0.57 & 0.52 & 0.57 \\
\hline $\mathrm{NDF}, \mathrm{kg} / \mathrm{d}$ & 8.17 & 8.33 & 0.29 & 0.71 & 0.56 \\
\hline MP, kg/d & 2.10 & 2.17 & 0.41 & 0.27 & 0.34 \\
\hline $\mathrm{ME}, \mathrm{MJ} / \mathrm{d}$ & 262 & 270 & 6.56 & 0.42 & 0.57 \\
\hline ME balance, $\mathrm{MJ} / \mathrm{d}$ & -47.3 & -56.4 & 8.69 & 0.46 & 0.25 \\
\hline
\end{tabular}




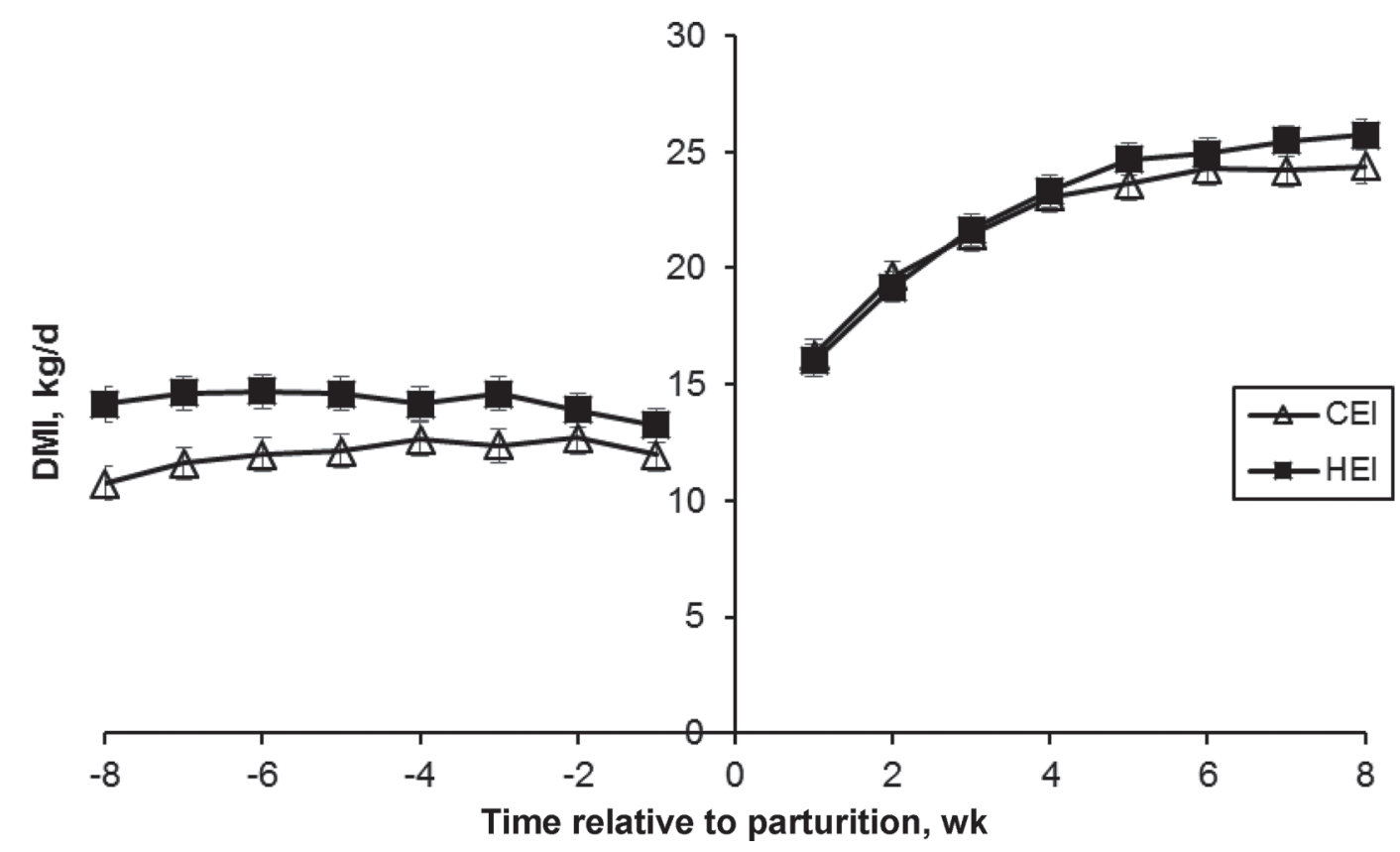

Figure 1. Dry matter intake of cows fed 2 levels of energy in the dry period: CEI $(\Delta)=108 \%$ of the ME requirements of grass silage, wheat straw, and rapeseed meal $(55 / 45 / 5 \%)$; HEI $(\mathbf{\square})=141 \%$ of the ME requirements of grass silage during wk 8 to 1 prepartum. Values are LSM \pm $\mathrm{SE}$ of repeated-measures analysis $(\mathrm{n}=16)$. Pooled $\mathrm{SE}=0.50 \mathrm{~kg} / \mathrm{d}$ prepartum, $0.57 \mathrm{~kg} / \mathrm{d}$ postpartum. Effects of diet prepartum $(P=0.002)$, diet $\times$ time prepartum $(P=0.64)$, diet postpartum $(P=0.52)$, and diet $\times$ time postpartum $(P=0.57)$.

$(P=0.09)$. We found a tendency for greater insulin levels in HEI cows than in CEI cows during the dry period $(P=0.07)$, the difference being most pronounced during the last 4 wk before parturition (diet $\times$ time, $P=0.08 ;$ Figure 4$)$. The insulin concentration did not differ between treatments after parturition. We did not observe a difference in either the plasma glucagon concentration or the glucagon:insulin ratio during the experimental period. The average plasma concentration of NEFA did not differ prepartum, but the increase of

Table 3. Effect of dry period energy intake and diet composition on body composition

\begin{tabular}{|c|c|c|c|c|}
\hline Item & $\mathrm{CEI}^{1}$ & $\mathrm{HEI}^{2}$ & SEM & $P$-value \\
\hline \multicolumn{5}{|l|}{ Prepartum } \\
\hline BCS at -8 wk & 3.5 & 3.4 & 0.20 & 0.37 \\
\hline BCS at $-5 \mathrm{~d}$ & 3.7 & 3.8 & 0.20 & 0.78 \\
\hline BCS change & 0.14 & 0.37 & 0.08 & 0.07 \\
\hline BW at $-8 \mathrm{wk}, \mathrm{kg}$ & 740 & 725 & 39.0 & 0.12 \\
\hline $\mathrm{BW}$ at $-5 \mathrm{~d}, \mathrm{~kg}$ & 781 & 800 & 39.3 & 0.91 \\
\hline BW change, $\mathrm{kg} / \mathrm{d}$ & 0.8 & 1.4 & 0.16 & 0.03 \\
\hline Calf weight, $\mathrm{kg}$ & 41.2 & 41.0 & 1.73 & 0.91 \\
\hline Back fat thickness at $-14 \mathrm{~d},{ }^{3} \mathrm{~mm}$ & 3.7 & 5.4 & 1.10 & 0.21 \\
\hline Back muscle diameter at $-14 \mathrm{~d},{ }^{3} \mathrm{~mm}$ & 51.3 & 52.2 & 2.29 & 0.65 \\
\hline \multicolumn{5}{|l|}{ Postpartum } \\
\hline BCS at +8 wk & 2.9 & 3.1 & 0.21 & 0.37 \\
\hline $\mathrm{BW}$ at $+1 / 2 \mathrm{~d}, \mathrm{~kg}$ & 719 & 718 & 39.8 & 0.98 \\
\hline $\mathrm{BW}$ at $+8 \mathrm{wk}, \mathrm{kg}$ & 700 & 692 & 18.9 & 0.50 \\
\hline BW change, $\mathrm{kg} / \mathrm{d}$ & -0.6 & -0.8 & 0.26 & 0.73 \\
\hline Log back fat thickness, ${ }^{3,4} \mathrm{~mm}$ & $1.12(3.1)$ & $1.35(3.9)$ & 0.262 & 0.36 \\
\hline Back fat thickness change ${ }^{5} \mathrm{~mm}$ & -0.6 & -1.0 & 0.44 & 0.51 \\
\hline Back muscle diameter, $\mathrm{mm}^{3}$ & 45.3 & 47.8 & 2.17 & 0.01 \\
\hline Back muscle diameter change ${ }^{5} \mathrm{~mm}$ & -9.2 & -6.6 & 1.6 & 0.28 \\
\hline
\end{tabular}

${ }^{1} \mathrm{CEI}=$ controlled energy intake during the 8 -wk dry period providing $108 \%$ of ME requirements/d.

${ }^{2} \mathrm{HEI}=$ ad libitum energy intake during the 8 -wk dry period providing $141 \%$ of ME requirements $/ \mathrm{d}$.

${ }^{3}$ Measured with ultrasound on the longissimus dorsi muscle (pars lumbalis).

${ }^{4}$ Values after transformation; back-transformed values are given in parentheses.

${ }^{5}$ The change from $\mathrm{d}-14$ to $\mathrm{d}+28$ relative to parturition. 


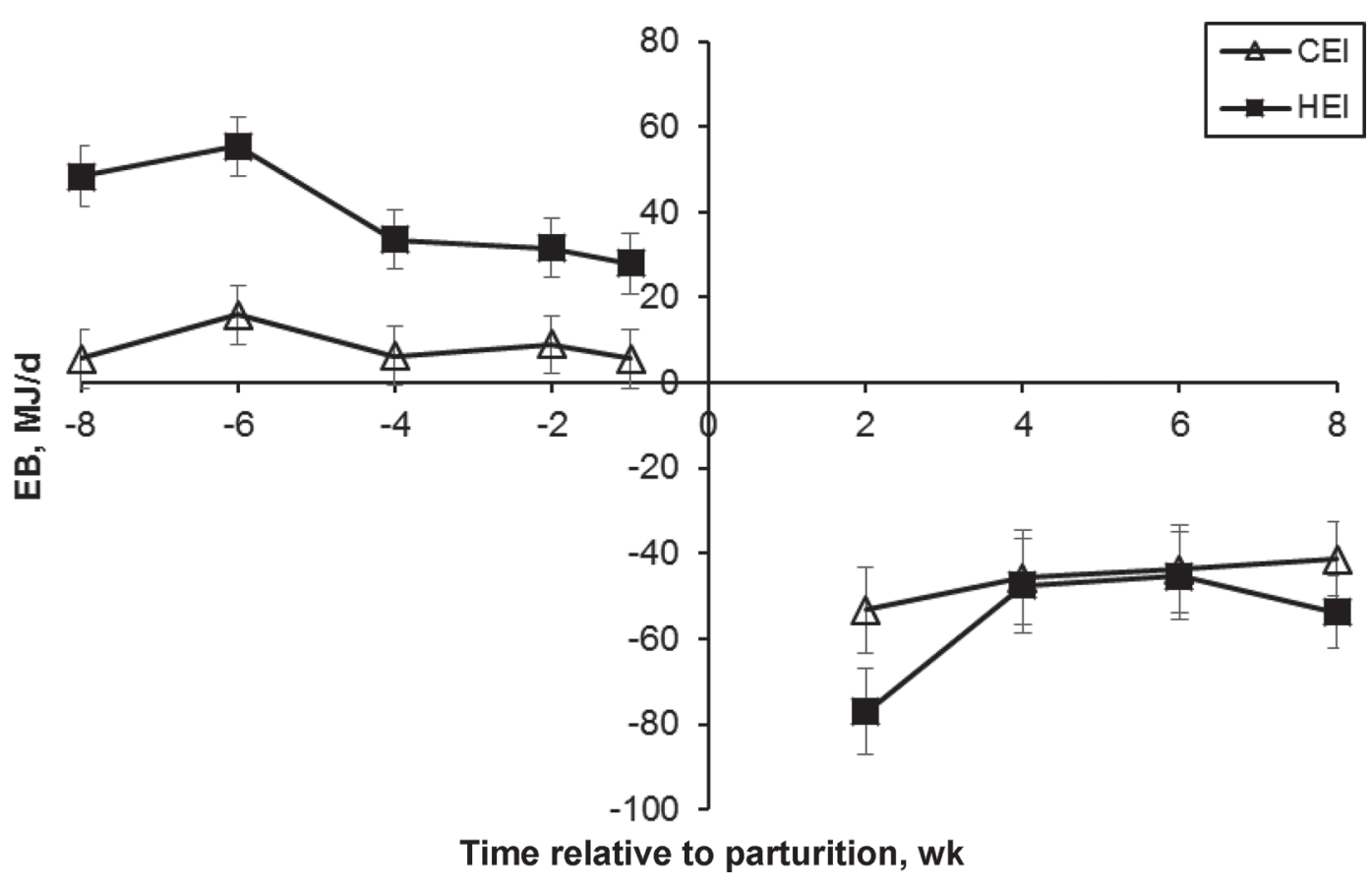

Figure 2. Metabolizable energy balance (EB) of cows fed 2 levels of energy in the dry period: CEI $(\Delta)=108 \%$ of the ME requirements of grass silage, wheat straw, and rapeseed meal (55/45/5\%); HEI $(\mathbf{\square})=141 \%$ of the ME requirements of grass silage during wk 8 to 1 prepartum. Values are $\mathrm{LSM} \pm \mathrm{SE}$ of repeated-measures analysis $(\mathrm{n}=16)$. Pooled $\mathrm{SE}=4.8 \mathrm{MJ} / \mathrm{d}$ prepartum, $8.7 \mathrm{MJ} / \mathrm{d}$ postpartum. Effects of diet prepartum $(P=0.004)$, diet $\times$ time prepartum $(P=0.51)$, diet postpartum $(P=0.46)$, and diet $\times$ time postpartum $(P=0.25)$.

NEFA concentration during the last week of pregnancy tended to be steeper in CEI cows than in HEI cows (diet $\times$ time, $P=0.07$; Figure 5). After parturition, there were no differences in the average plasma NEFA concentration. Plasma BHB concentrations were greater in HEI cows than in CEI cows during the dry period $(P=0.006$; Figure 6$)$. After calving, the BHB levels increased until 2 and 4 wk of lactation in HEI and CEI cows, respectively. The CEI cows had higher BHB at wk 6 and 8 (diet $\times$ time, $P=0.07$ ). Plasma glycerol concentrations were not affected by the prepartal dietary treatments. Plasma $3-\mathrm{MH}$ tended to be higher in CEI cows than in HEI cows on $-12 \mathrm{~d}$ prepartum $(P$ $=0.09$ ), whereas no differences in plasma $3-\mathrm{MH}$ were found after parturition.

\section{Milk Production and Composition}

The milk production parameters are depicted in Table 5. The average milk yield and the ECM were not affected by the treatments. However, a significant diet $\times$ time interaction was observed, indicating higher milk yield in HEI cows than in CEI cows from wk 5 onward, the average difference being $5.3 \pm 1.6 \mathrm{~kg}$ on wk 7 and $8(P=0.007$; Supplemental Figure S3, https://doi.org/ 10.3168/jds.2018-14728). The feed efficiency (ECM/kg of DMI) was not affected by prepartal diet. Increase in feed efficiency tended to be greater in HEI cows than in CEI cows during the first 2 wk of lactation; the difference was most pronounced in wk 2 (diet $\times$ time, $P=$ $0.07)$. Milk fat percentage was greater in HEI cows than in CEI cows on lactation wk 1,2 , and 6 (diet $\times$ time, $P$ $=0.003$ ). Milk protein and lactose concentrations were not different between treatments. Milk urea tended to be higher in HEI cows than in CEI cows over time, the difference being most pronounced on lactation wk 4 (diet $\times$ time, $P=0.09$ ). The fat yield was not different between treatments. The protein yield tended to be higher in HEI cows than in CEI cow from wk 6 onward, the difference being greatest on wk 8 (diet $\times$ time, $P=$ 0.05 ). The lactose yield was higher in HEI cows than in CEI cows on wk 8 (diet $\times$ time, $P=0.01)$.

\section{Glucose, Insulin, and NEFA Dynamics During the IVGTT}

Basal and peak concentrations and clearance rate of glucose prepartum were not affected by the dietary treatments (Table 6). However, glucose AUC was smaller in HEI cows than in CEI cows during the prepartal IVGTT $\left(\mathrm{AUC}_{240} ; P=0.02\right.$; Figure $\left.7 \mathrm{~A}\right)$. Prepartal diet affected the endogenous insulin response to glucose infusion during the IVGTT at $13 \mathrm{~d}$ before parturition (Figure $7 \mathrm{~B})$. The peak concentration $(P=0.01)$ and 
Table 4. Effect of dry period energy intake and diet composition on blood hormone and metabolite concentration

\begin{tabular}{|c|c|c|c|c|c|}
\hline Item & $\mathrm{CEI}^{1}$ & $\mathrm{HEI}^{2}$ & SEM & \multicolumn{2}{|c|}{$P$-value } \\
\hline \multicolumn{6}{|l|}{ Prepartum } \\
\hline Log insulin, ${ }^{3} \mu \mathrm{IU} / \mathrm{mL}$ & $2.67(14.4)$ & $3.00(20.1)$ & 0.151 & 0.07 & 0.08 \\
\hline $1 /$ glucagon, ${ }^{3,4} \mathrm{pg} / \mathrm{mL}$ & $0.0078(128.2)$ & $0.0071(140.8)$ & 0.0006 & 0.45 & 0.33 \\
\hline Log glucagon:insulin,$^{3,4} \mathrm{~mol} / \mathrm{mol}$ & $-1.00(0.37)$ & $-1.03(0.36)$ & 0.126 & 0.86 & 0.60 \\
\hline Log glycerol, ${ }^{3,5} \mu \mathrm{mol} / \mathrm{L}$ & $3.75(42.5)$ & $3.83(46.1)$ & 0.055 & 0.32 & 0.93 \\
\hline $3-\mathrm{MH}$ at $\mathrm{d}-12, \mu \mathrm{mol} / \mathrm{L}$ & 7.48 & 5.80 & 0.734 & 0.09 & - \\
\hline \multicolumn{6}{|l|}{ Postpartum } \\
\hline Glucose, mmol/L & 3.2 & 3.4 & 0.09 & 0.09 & 0.45 \\
\hline Log insulin, $\mu \mathrm{IU} / \mathrm{mL}$ & $2.12(8.3)$ & $2.22(9.2)$ & 0.107 & 0.52 & 0.37 \\
\hline 1/glucagon, ${ }^{3,6} \mathrm{pg} / \mathrm{mL}$ & $0.0069(144.9)$ & $0.0076(131.6)$ & 0.0006 & 0.43 & 0.37 \\
\hline Log glucagon:insulin ${ }^{6} \mathrm{~mol} / \mathrm{mol}$ & $-0.33(0.72)$ & $-0.50(0.61)$ & 0.142 & 0.40 & 0.26 \\
\hline
\end{tabular}

${ }^{1} \mathrm{CEI}=$ controlled energy intake during the 8 -wk dry period providing $108 \%$ of ME requirements/d.

${ }^{2} \mathrm{HEI}=$ ad libitum energy intake during the 8 -wk dry period providing $141 \%$ of ME requirements/d.

${ }^{3}$ Values after transformation; back-transformed values are given in parenthesis.

${ }^{4}$ Sampled on $\mathrm{d}-56,-12$, and -3 relative to parturition.

${ }^{5}$ Sampled on $\mathrm{d}-56,-42,-12,-7,-5,-3$, and -1 relative to parturition.

${ }^{6}$ Sampled on d 1, 7, 14, and 28 relative to parturition.

${ }^{7}$ Plasma 3-methylhistidine concentration sampled on d 1, 7, and 28 relative to parturition.

the AUC of insulin during the first hour of the IVGTT $(P=0.03)$ was greater in HEI cows than in CEI cows, and the AUC during the 240-min IVGTT tended to be greater in HEI cows than in CEI cows $(P=0.05)$. The effect of the interval between the IVGTT and the day of calving was significant during the prepartal IVGTT for insulin peak concentration and insulin AUC $(P<$ $0.05)$, indicating that cows closer to their due date had smaller insulin AUC and lower peak concentrations. The basal and nadir concentrations of NEFA as well as clearance rate and AUC did not differ between treatments pre- and postpartum (Figure 7C). However, during the prepartal IVGTT, the NEFA model-derived parameter for latency was greater $(P=0.04)$ and basal NEFA estimated by NEFA model analysis tended to be smaller $(P=0.09)$ in HEI cows than in CEI cows.

The dry period dietary treatment had minor effect on MM estimates, as the only significant difference was higher $\mathrm{AIR}_{\mathrm{G}}$ in HEI cows than in CEI cows $(P=0.002)$ during the prepartal IVGTT (Table 6 ). The effect of the interval between the IVGTT and the day of calving was significant during the prepartal IVGTT for DI $(P$ $=0.03$ ), showing that the closer the due date, the lower the DI. The values of Sg, SI, and DI did not differ between the treatments at either time point $(P>0.10)$.

We found no treatment differences in glucose, insulin, and NEFA responses to infusion of glucose after parturition $(P>0.10$; Figure 8$)$. The basal NEFA had a strong positive correlation with NEFA decrement in both prepartal $(\mathrm{r}=0.98 ; P<0.001)$ and postpartal $(\mathrm{r}=0.74 ; P<0.001)$ IVGTT. Similarly, basal NEFA had a negative association with NEFA $\mathrm{AUC}_{60}$ in both prepartal $(\mathrm{r}=-0.69 ; P<0.004)$ and postpartal $(\mathrm{r}=$ $-0.50 ; P=0.049)$ IVGTT.

\section{DISCUSSION}

The main objective of this study was to investigate whether controlling energy intake of dairy cows by diluting a moderately digestible GS with WS during the 8-wk dry period affects whole-body IR and tissue deposition and mobilization during early lactation compared with ad libitum access to GS. We assessed these conditions by measuring the changes of plasma metabolite and hormone concentrations under basal and stimulated conditions as well as by investigating the changes in $\mathrm{BCS}, \mathrm{BW}$, and production performance of early lactation. Given that GS is the main source of forage for dairy cows in many Northern European countries during the indoor feeding period, we previously assessed the effects of different allowances of sole GS during the dry period on metabolic and production responses (Salin et al., 2017; T. Kokkonen, S. Salin, S. Jaakkola, J. Taponen, K. Elo, and A. Vanhatalo, 


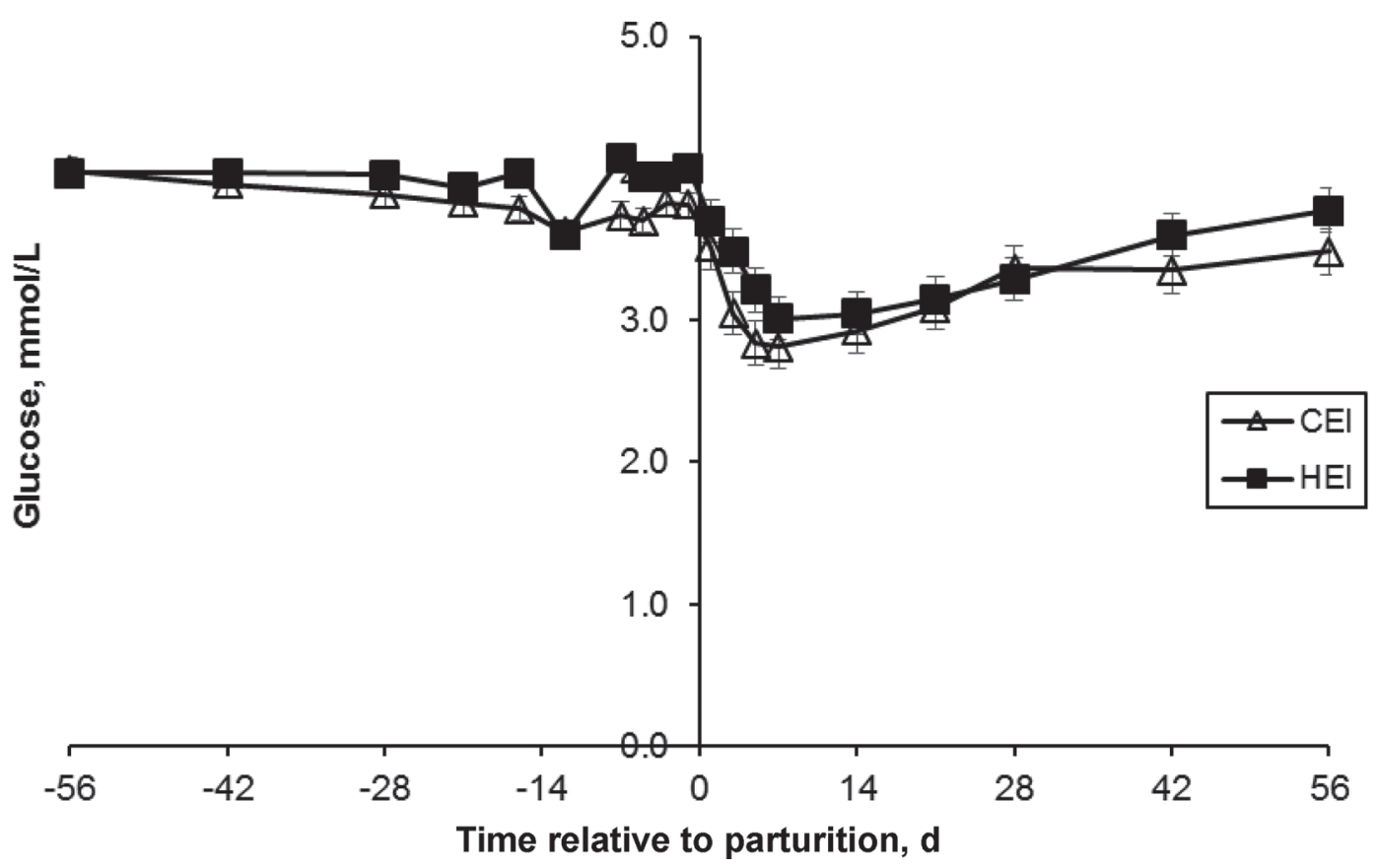

Figure 3. Plasma glucose concentration of cows fed 2 levels of energy in the dry period: CEI $(\Delta)=108 \%$ of the ME requirements of grass silage, wheat straw, and rapeseed meal (55/45/5\%); HEI $(\boldsymbol{\square})=141 \%$ of the ME requirements of grass silage during wk 8 to 1 prepartum. Values are LSM \pm SE of repeated-measures analysis $(\mathrm{n}=16)$. Effects of diet prepartum $(P=0.049)$, diet $\times$ time prepartum $(P=0.06)$, diet postpartum $(P=0.09)$, and diet $\times$ time postpartum $(P=0.45)$.

unpublished data). In the present experiment, GS as a sole forage source and GS diluted with straw fed ad libitum where chosen for comparison to investigate a more practical feeding regimen for loose-housing systems.

\section{DMI}

The prepartal DMI was well maintained in CEI cows in accordance with earlier studies showing that controlling energy intake by restriction of the amount of TMR or GS (Agenäs et al., 2003; T. Kokkonen, S. Salin, S. Jaakkola, J. Taponen, K. Elo, and A. Vanhatalo, unpublished data) or the composition of the diet (Rabelo et al., 2003; Vickers et al., 2013) prevented the decline in DMI during the last weeks of pregnancy. The moderate decline in prepartal DMI of HEI cows during the last 4 wk prepartum in the current study $(0.9 \pm 0.73$ $\mathrm{kg} / \mathrm{d}$ ) is in agreement with Agenäs et al. (2003), who reported an average of $1 \mathrm{~kg} / \mathrm{d}$ decline in DMI during the same time period in overfed cows on GS-based diets. In comparison, the DMI decline in cows fed ad libitum GS with or without barley straw in a series of experiments during the final 5 wk of the dry period (NDF range $=452-689 \mathrm{~g} / \mathrm{kg}$ of DM) was on average 1.47 $\mathrm{kg} / \mathrm{d}$, half of which occurred during the week preceding calving (Dewhurst et al., 2010). Although we did not investigate digestibility of the nutrients in this study, the lower intake of CEI is at least partly attributable to the lower nutrient digestibility resulting from inherent characteristics of straw fiber (Dewhurst et al., 2000).

We did not find any difference in postpartal DMI in agreement with other studies with moderate (30-40\%) overfeeding of energy during the dry period (Butler et al., 2011; Mann et al., 2015; T. Kokkonen, S. Salin, S. Jaakkola, J. Taponen, K. Elo, and A. Vanhatalo, unpublished data). These results contrast with previous studies showing that high-energy diets (150-160\% of energy requirement) during late pregnancy resulted in lower feed intake during early lactation in maize silage-based diets (Dann et al., 2006; Douglas et al., 2006; Janovick and Drackley, 2010). The moderately but statistically significant lower concentrate DMI in CEI cows than HEI cows after parturition, especially during the second month of lactation, could possibly be a carryover effect of the prepartal TMR. The inclusion of WS in the CEI diet may have affected the rumen adaptation mechanism (e.g., papillae development and structural changes; Odongo et al., 2006; Steele et al., 2011). The very moderate amount of concentrates given for only $12 \pm 5 \mathrm{~d}$ (mean $\pm \mathrm{SD}$ ) prepartum may have resulted in a too-low NSC intake of CEI to optimize the adaptation to a concentrate-rich lactation ration after parturition. In fact, higher contents of digestible 
carbohydrate (e.g., starch) enhanced the overall VFA absorption capacity via rumen papillae development (Goodlad, 1981; Dirksen et al., 1985).

\section{Plasma Metabolites and Hormones}

Higher prepartal concentration of basal glucose in cows fed high-energy diets compared with controlledenergy diets during the entire 8-wk dry period is analogous with earlier research (Douglas et al., 2006; Janovick et al., 2011; Mann et al., 2016), whereas we did not observe a corresponding difference when different amounts of GS were fed to dry cows during the 6-wk dry period (T. Kokkonen, S. Salin, S. Jaakkola, J. Taponen, K. Elo, and A. Vanhatalo, unpublished data). The higher blood glucose concentration in HEI is most likely a result of increased availability of propionate for hepatic gluconeogenesis (Janovick et al., 2011; Mann et al., 2016), as the TMR with high amounts of straw lacks precursors for gluconeogenesis. Corresponding with higher glucose levels, the HEI cows tended to have higher insulin concentration during the prepartal period, analogous to other recent studies showing that energy overfeeding during the dry period resulted in higher prepartum insulin concentrations compared with restricted energy feeding (Holtenius et al., 2003; Douglas et al., 2006; Janovick et al., 2011). The higher but still moderate plasma BHB in HEI cows compared with CEI cows prepartum is most likely a consequence of a greater ruminal butyrate production due to higher intake of GS and not an indicator of metabolic imbalance (Roche et al., 2013). In line with this, the mRNA expression of mitochondrial mitochondrial carnitine palmitoyltransferase 1A activity in the liver at $\mathrm{d}-14$, 1 , and $7 \mathrm{~d}$ relative to parturition was not changed in the current animals (Selim et al., 2015), suggesting that the translocation of fatty acid derivatives to hepatic mitochondrial $\beta$-oxidation was unchanged around parturition. The results agree with earlier studies reporting lower prepartal BHB in cows on controlled-energy diets than in cows on higher energy diets with a normal or low BCS at dry-off (Mann et al., 2015; Little et al., 2016). Butler et al. (2011) showed greater blood concentrations of BHB in GS-fed cows than in cows fed a wheat-based TMR at 1 wk before parturition and during the first 4 wk postpartum without any treatment effect on incidence of ketosis.

The tendency for higher plasma glucose in HEI after parturition is inconsistent with the absence of differences in plasma glucagon concentration or glucagon: insulin ratio, suggesting no differences in gluconeogenesis from AA and lactate (Aschenbach et al., 2010). The higher plasma glucose is also inconsistent with the results of Selim et al. (2015) from the same cows, suggesting attenuated increase of hepatic gluconeogenic activity from propionate in HEI, as the hepatic phos-

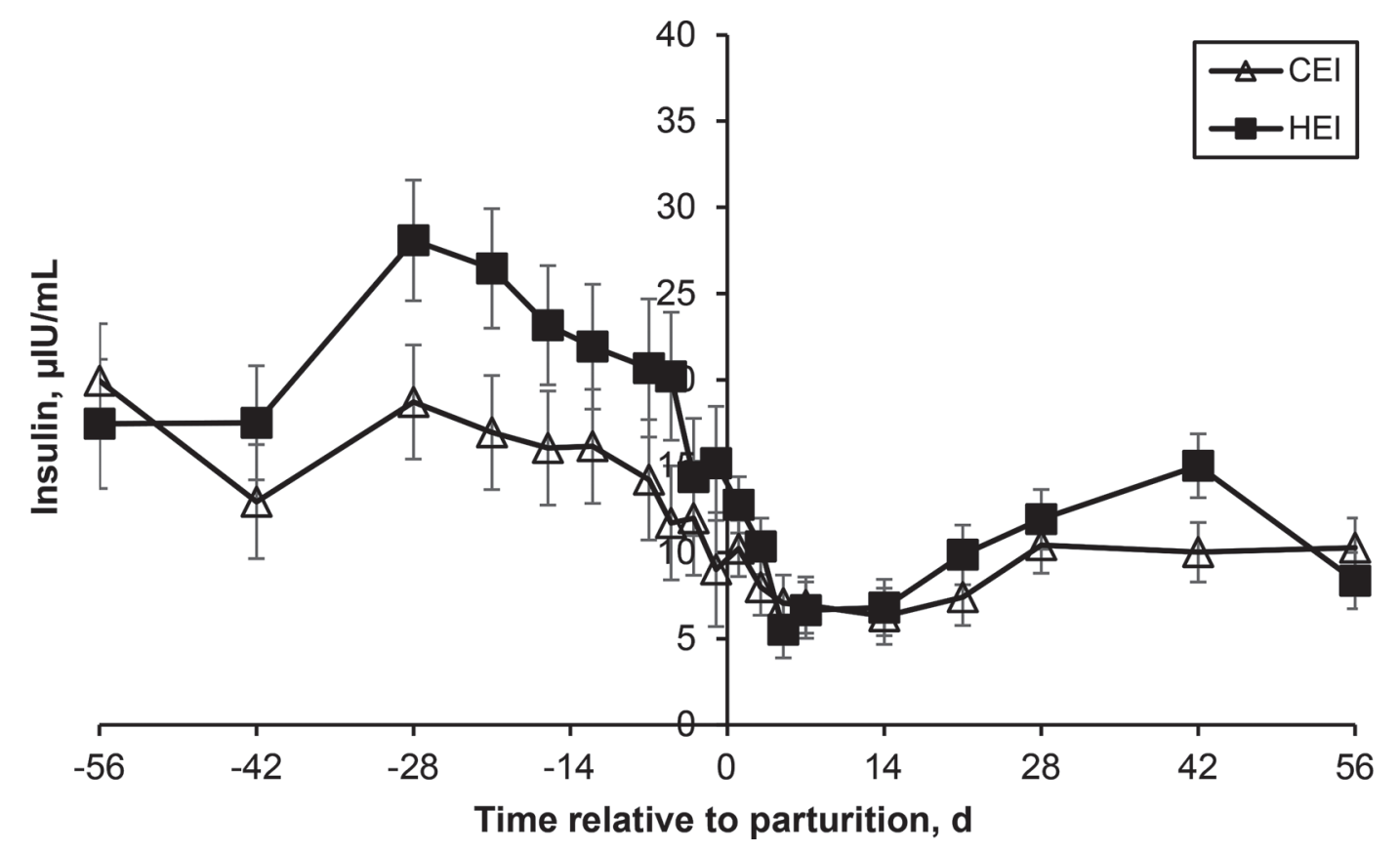

Figure 4. Plasma insulin concentration of cows fed 2 levels of energy in the dry period: CEI $(\Delta)=108 \%$ of the ME requirements of grass silage, wheat straw, and rapeseed meal (55/45/5\%); HEI $(\boldsymbol{\square})=141 \%$ of the ME requirements of grass silage during wk 8 to 1 prepartum. Values are back-transformed LSM $\pm \mathrm{SE}$ from repeated-measures analysis of log-transformed data $(\mathrm{n}=16)$. Effects of diet prepartum $(P=0.07)$, diet $\times$ time prepartum $(P=0.08)$, diet postpartum $(P=0.52)$, and diet $\times$ time postpartum $(P=0.37)$. 


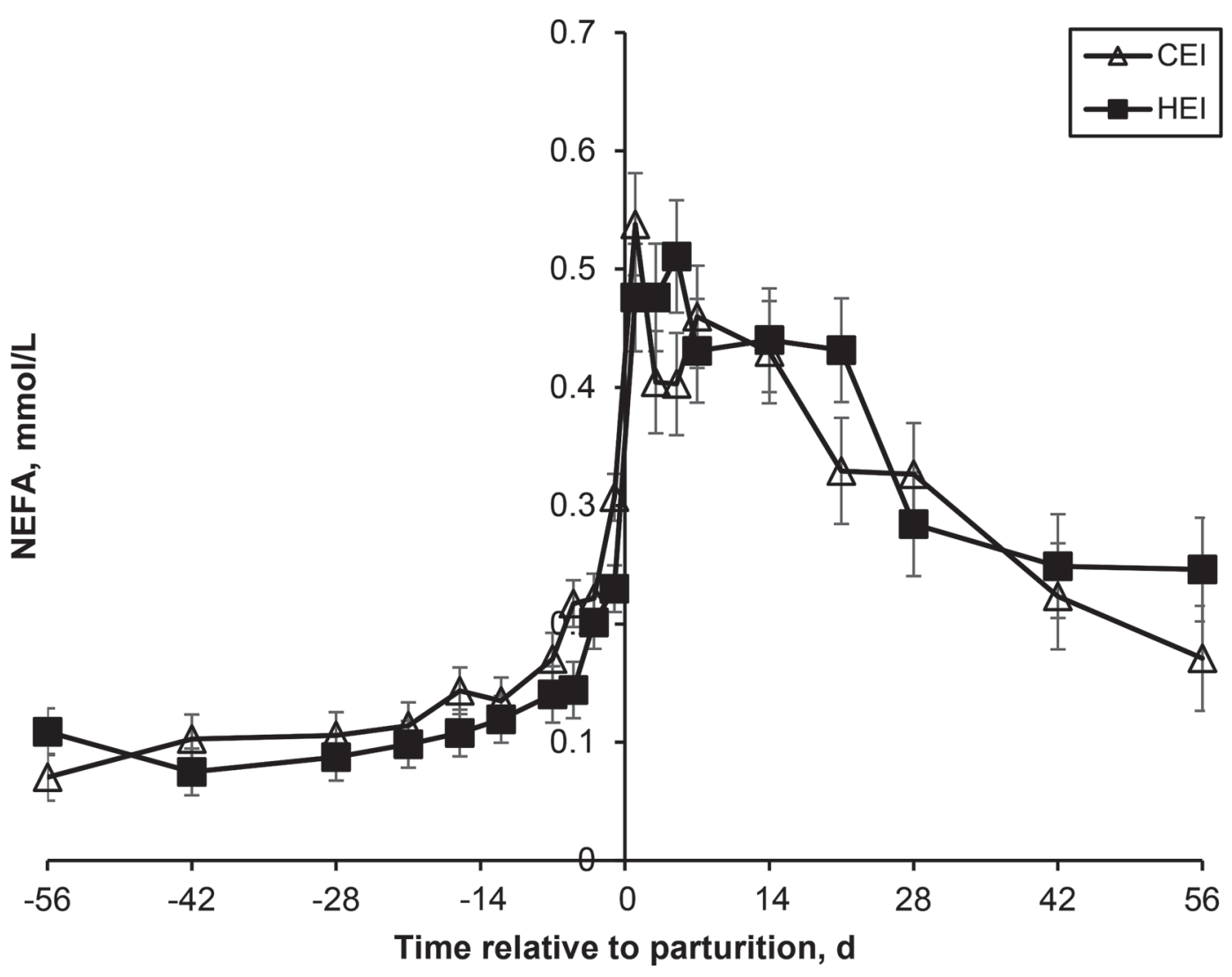

Figure 5. Plasma nonesterified fatty acid (NEFA) concentration of cows fed 2 levels of energy in the dry period: CEI $(\Delta)=108 \%$ of the ME requirements of grass silage, wheat straw, and rapeseed meal $(55 / 45 / 5 \%)$; HEI $(\mathbf{\square})=141 \%$ of the ME requirements of grass silage during wk 8 to 1 prepartum. Values are back-transformed LSM \pm SE from repeated-measures analysis of log-transformed data $(\mathrm{n}=16)$. Effects of diet prepartum $(P=0.26)$, diet $\times$ time prepartum $(P=0.07)$, diet postpartum $(P=0.62)$, and diet $\times$ time postpartum $(P=0.28)$.

phoenolpyruvate carboxykinase 1 mRNA expression was downregulated in HEI cows but not in CEI cows at $\mathrm{d} 1$ and 7 of lactation compared with $\mathrm{d}-8$. The higher BHB concentration in CEI cows than in HEI cows at d 42 and 56 indicates compensation of insufficient supply of glucose precursors, as suggested by lower concentrate DMI. The higher BHB concentration may have also served as a tissue-protective mechanism in CEI cows because BHB has been shown to inhibit basal AT lipolysis in vitro in a dose-dependent matter (van der Drift et al., 2013). Thus, the feedback mechanisms may have prevented toxic effects of high BHB levels on tissues by shutting down further release of additional NEFA (Rukkwamsuk et al., 1998). This may explain the lack of differences in NEFA concentrations between CEI and HEI at d 42 and 56.

\section{Indicators of Tissue Accretion and Mobilization}

The cows in HEI gained more BW during the 8-wk dry period. Although the difference in BW gain between energy levels was greater in the present experiment than in our previous experiment (T. Kokkonen, S. Salin, S. Jaakkola, J. Taponen, K. Elo, and A. Vanhatalo, unpublished data), we expected a larger response of surplus EI on BW and BCS gain before calving. According to the Finnish nutrient requirements (Luke, 2017), an average ME difference of $34 \mathrm{MJ} / \mathrm{d}$ between the treatments during the dry period should have resulted in an approximate difference of $1 \mathrm{~kg} / \mathrm{d}$ in daily BW change instead of the reported value of $0.6 \mathrm{~kg} / \mathrm{d}$. Thus, our findings support recent studies postulating that the ME requirements of pregnant cows may be underestimated in different energy calculation systems and that the actual requirements for maintenance and lactation may be larger than reported (Mandok et al., 2013; Kokkonen and Vanhatalo, 2014). Moreover, it seems that cows in a fairly good body condition at dryoff, as all the cows in our study were, do not gain much BCS (0.3 unit on average) in GS-based feeding during an 8-wk dry period, in agreement with our recent study with a dry period of $6 \mathrm{wk}$ (T. Kokkonen, S. Salin, S. Jaakkola, J. Taponen, K. Elo, and A. Vanhatalo, unpublished data). However, higher prepartal energy 
Table 5. Effect of dry period energy intake and diet composition on milk production responses

\begin{tabular}{lccccc}
\hline & & & & \multicolumn{2}{c}{$P$-value } \\
\cline { 5 - 6 } Item & CEI $^{1}$ & HEI $^{2}$ & SEM & Diet & Diet $\times$ time \\
\hline Milk, $\mathrm{kg} / \mathrm{d}$ & 40.1 & 42.8 & 1.32 & 0.18 & 0.007 \\
$\mathrm{ECM}, \mathrm{kg} / \mathrm{d}$ & 41.8 & 44.3 & 1.21 & 0.16 & 0.27 \\
$\mathrm{ECM} / \mathrm{kg}$ of DMI & 1.95 & 2.05 & 0.08 & 0.38 & 0.02 \\
Fat, g/d & 1,820 & 1,930 & 61.4 & 0.22 & 0.30 \\
Protein, g/d & 1,300 & 1,380 & 38.9 & 0.18 & 0.05 \\
Lactose, g/d & 1,770 & 1,830 & 78.4 & 0.58 & 0.01 \\
Milk composition & 47.5 & & & & \\
Fat, g/kg & 34.4 & 38.3 & 1.07 & 0.59 & 0.003 \\
Protein, g/kg & 45.4 & 45.3 & 0.51 & 0.96 & 0.57 \\
Lactose, g/kg & 29.0 & 29.8 & 0.29 & 0.76 & 0.55 \\
Urea, $\mathrm{mg} / 100 \mathrm{~mL}$ & & 1.86 & 0.72 & 0.09 \\
\hline
\end{tabular}

${ }^{1} \mathrm{CEI}=$ controlled energy intake during the 8 -wk dry period providing $108 \%$ of ME requirements/d.

${ }^{2} \mathrm{HEI}=$ ad libitum energy intake during the 8 -wk dry period providing $141 \%$ of ME requirements $/ \mathrm{d}$.

${ }^{3}$ Calculated according to Sjaunja et al. (1991).

intake affected the onset of excessive tissue mobilization near calving. The tendency for a more pronounced increase of plasma NEFA and higher plasma 3-MH in CEI cows in the weeks preceding calving indicates that CEI cows initiated the mobilization process at an earlier stage precalving.

In contrast to studies showing that postpartal BW losses and NEFA concentrations were lower when dietary energy intake was restricted prepartum (reflect- ing the positive effect of dry-period feeding level on EB postpartum) in TMR-fed dairy cows (Douglas et al., 2006; Janovick and Drackley, 2010; Janovick et al., 2011), we did not find any differences in BW and BCS losses or in plasma NEFA concentrations after parturition. Our data suggest that cows on GS-based diets pre- and postpartum are not prone to large changes in BCS and BW after parturition, concordant with studies on similar forage types (Agenäs et al., 2003; Vickers et

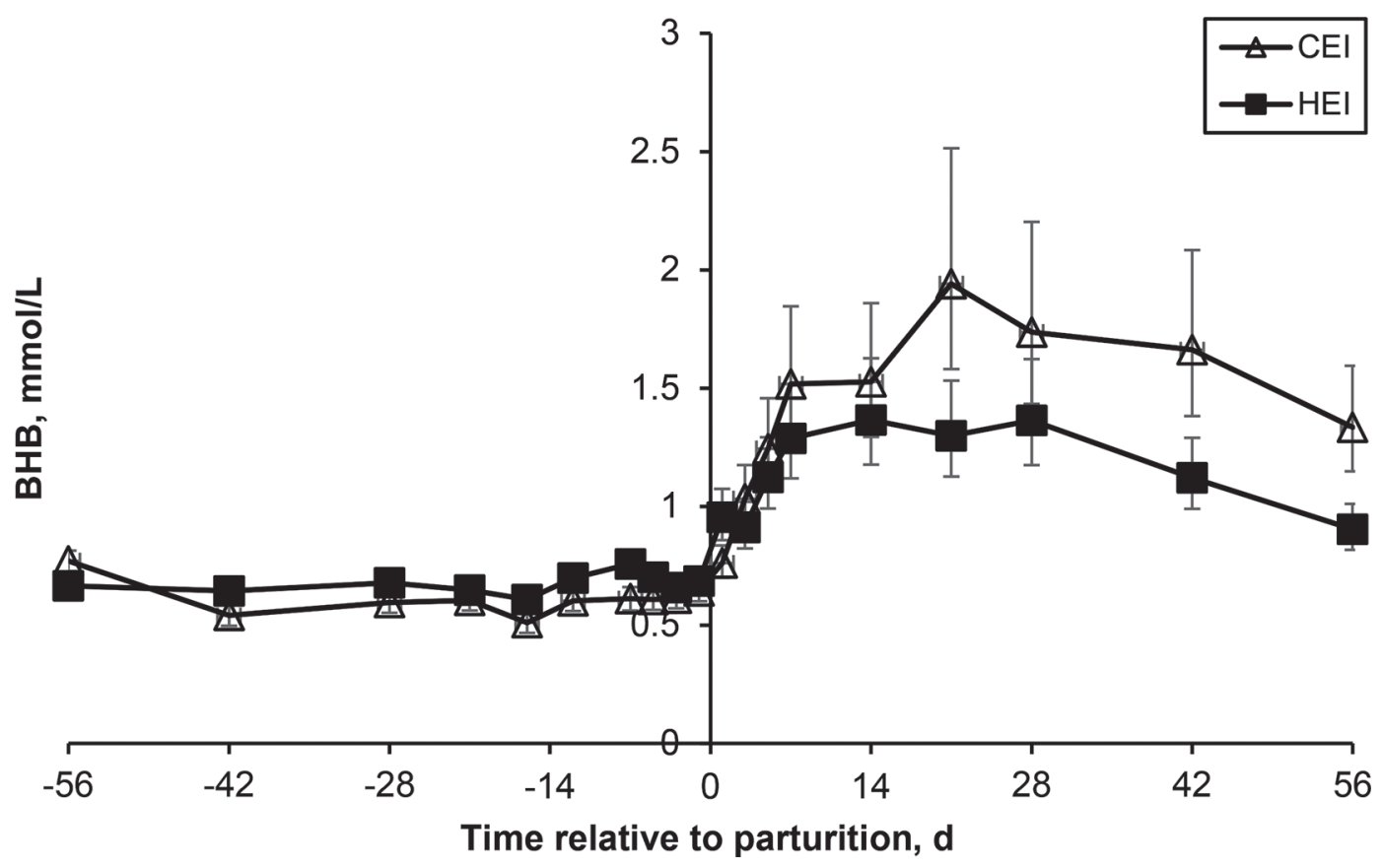

Figure 6. Plasma BHB concentration of cows fed 2 levels of energy in the dry period: CEI $(\Delta)=108 \%$ of the ME requirements of grass silage, wheat straw, and rapeseed meal $(55 / 45 / 5 \%)$; HEI $(\mathbf{\square})=141 \%$ of the ME requirements of grass silage during wk 8 to 1 prepartum. Prepartal values are LSM $\pm \mathrm{SE}$ of repeated-measures analysis. Postpartal values are back-transformed LSM \pm SE from repeated-measures analysis of reciprocally transformed data $(\mathrm{n}=16)$. Effects of diet prepartum $(P=0.006)$, diet $\times$ time prepartum $(P=0.27)$, diet postpartum $(P=0.32)$, and diet $\times$ time postpartum $(P=0.01)$. 
al., 2013; Little et al., 2016; T. Kokkonen, S. Salin, S. Jaakkola, J. Taponen, K. Elo, and A. Vanhatalo, unpublished data). More pronounced differences in prepartal BW changes on GS or maize silage diets have resulted in increased AT mobilization after parturition (Kokkonen et al., 2005; Douglas et al., 2006). Our results suggest that overfeeding GS-based diets has only a moderate effect on metabolic flexibility of transition dairy cows. Conversely, a recent review highlighted negative effects of overconditioning on maize silage-based diets with excessive AT mobilization on metabolic disorders of cows in early lactation (Drackley and Cardoso, 2014). The observed strong positive correlation of initial BCS and that of the BCS at $5 \mathrm{~d}$ before parturition is in agreement with T. Kokkonen, S. Salin, S. Jaakkola, J. Taponen, K. Elo, and A. Vanhatalo (unpublished data). These findings support the earlier suggestions (Friggens et al., 2004) implying that dairy cows have an inherent level of body reserves toward which their metabolism is aiming during late lactation and in the transition period to restore the genetically predestined body condition. Further, the absence of differences in BCS at calving or in the mobilization of body tissues after parturition implies that neither the BCS at calving (as suggested by, e.g., Roche et al., 2009, 2015; Pires et al., 2013) nor the prepartal energy intake per se were determinants of postpartal performance after parturition in the current study.

Table 6. Effect of dry period energy intake and diet composition on plasma glucose, insulin, and nonesterified fatty acid (NEFA) responses to intravenous glucose tolerance test (IVGTT; $0.25 \mathrm{~g}$ of glucose/ $\mathrm{kg}$ of BW) at d 13 before parturition and d 9 postpartum

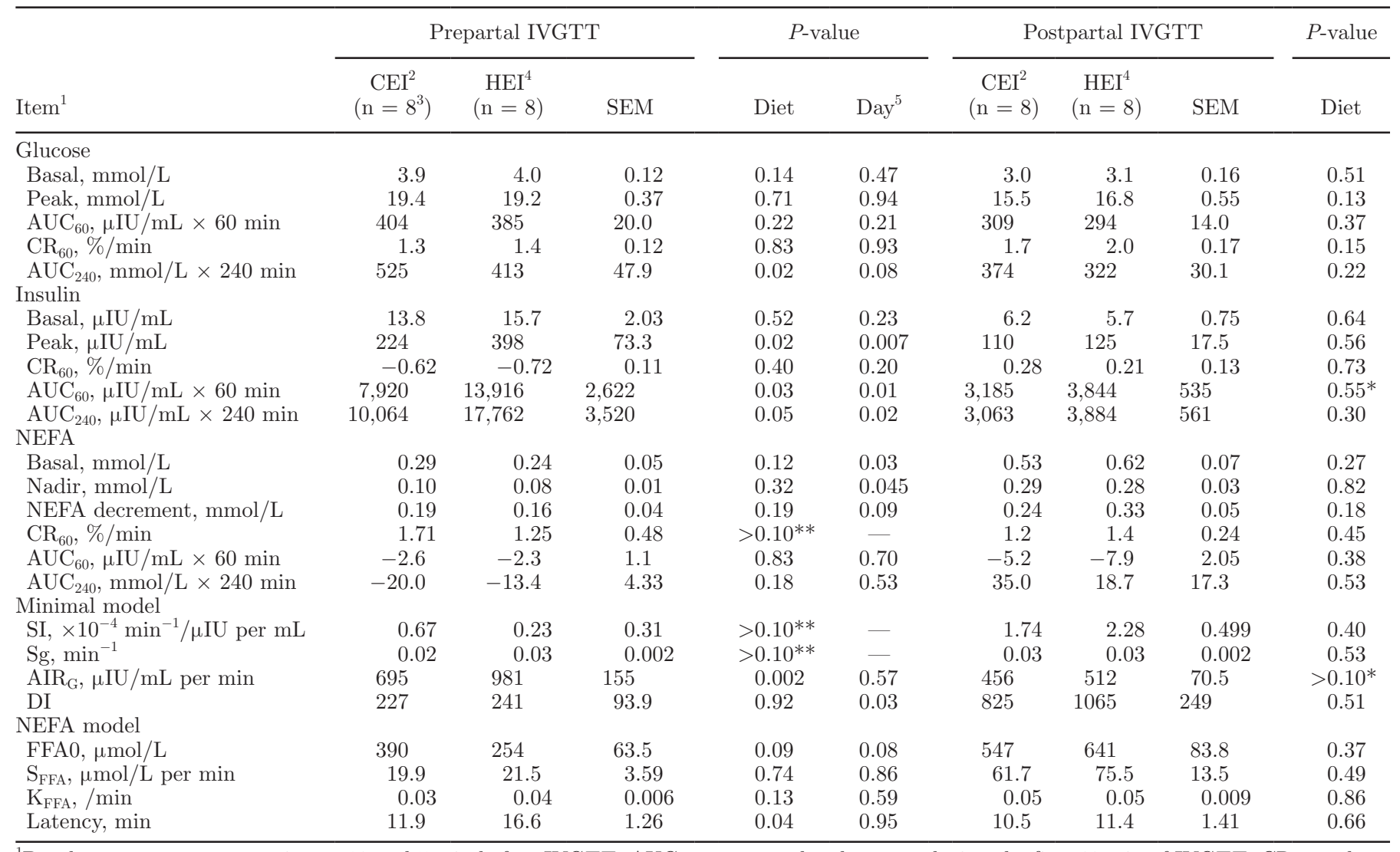

${ }^{1}$ Basal $=$ average concentration at 10 and 5 min before IVGTT; $\mathrm{AUC}_{60}=$ area under the curve during the first 60 min of IVGTT; CR $60=$ clearance rate during the first $60 \mathrm{~min}$ of IVGTT; $\mathrm{AUC}_{240}=$ area under the curve during $240 \mathrm{~min}$ of IVGTT [(mmol/L for glucose and NEFA; $\mu \mathrm{IU} /$ $\mathrm{mL}$ for insulin) $\times 240 \mathrm{~min}]$; NEFA decrement $=$ basal - nadir; $\mathrm{SI}=$ insulin sensitivity index; $\mathrm{Sg}=$ glucose effectiveness; AIR $_{\mathrm{G}}=$ acute insulin response to glucose load; $\mathrm{DI}=$ disposition index $\left(\mathrm{AIR}_{\mathrm{G}} \times \mathrm{SI}\right)$; FFA0 $=$ basal NEFA estimated by NEFA model analysis; $\mathrm{S}_{\mathrm{FFA}}=$ rate of entry of NEFA to the plasma pool; $K_{\mathrm{FFA}}=$ fractional disposition rate of NEFA from the plasma pool; latency = time until NEFA concentration begins to decline.

${ }^{2} \mathrm{CEI}=$ controlled energy intake during the 8-wk dry period providing $108 \%$ of ME requirements.

${ }^{3} \mathrm{n}=7$ for NEFA statistics.

${ }^{4} \mathrm{HEI}=$ ad libitum energy intake during the 8-wk dry period providing $141 \%$ of ME requirements.

${ }^{5}$ Day $=$ number of days to expected parturition.

${ }^{*} P$-values after natural logarithmic transformation. ${ }^{*} P$-values from Friedman's nonparametric testing. 

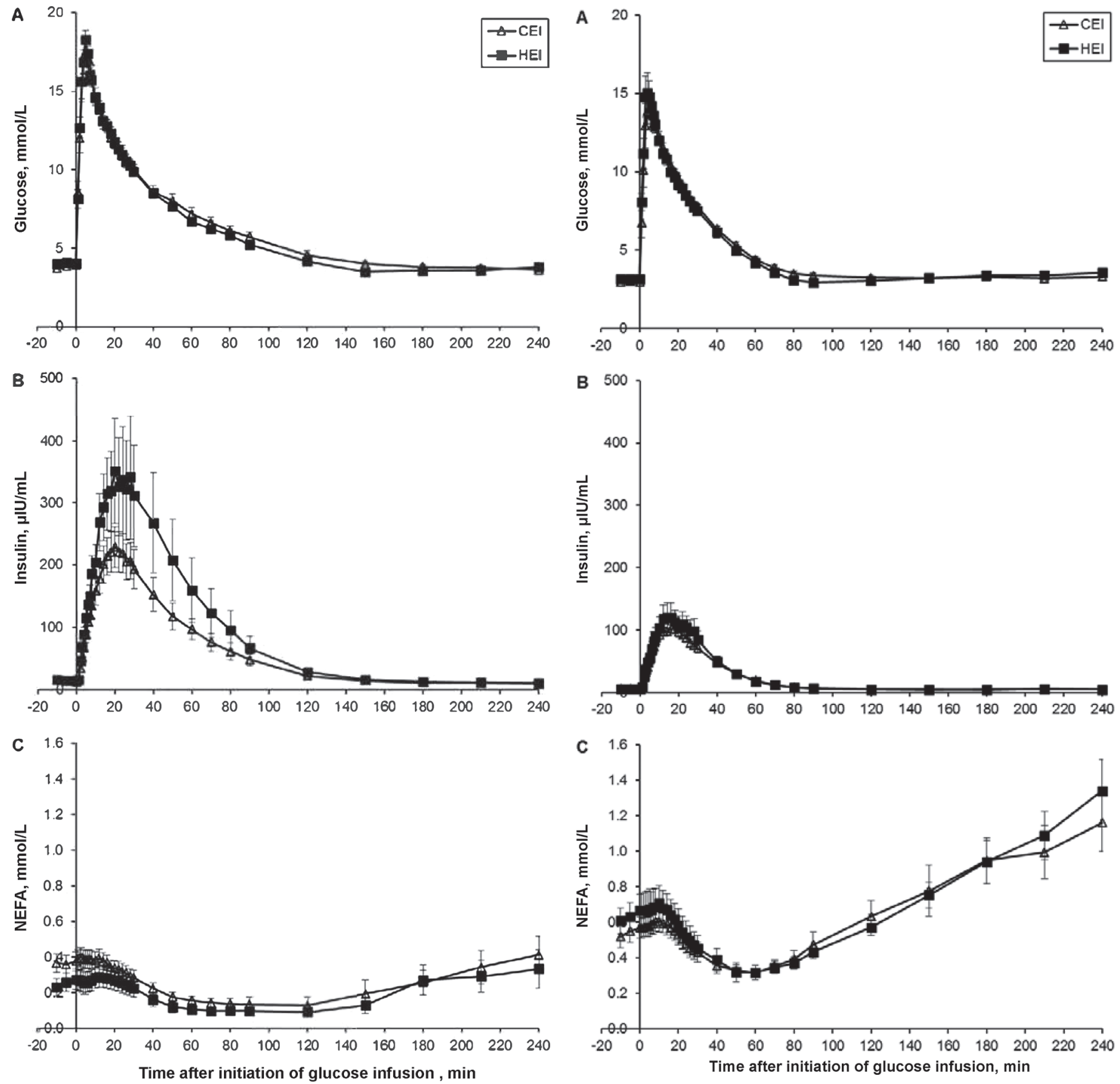

Figure 7. Treatment effects on plasma (A) glucose, (B) insulin, and $(\mathrm{C})$ nonesterified fatty acid (NEFA) concentration during intravenous glucose tolerance tests $(0.25 \mathrm{~g}$ of glucose i.v. $/ \mathrm{kg}$ of $\mathrm{BW})$ performed $13 \pm 5 \mathrm{~d}$ before parturition in dairy cows fed 2 levels of energy in the dry period: CEI $(\Delta)=108 \%$ of the ME requirements of grass silage, wheat straw, and rapeseed meal (55/45/5\%); HEI $(\mathbf{\square})=141 \%$ of the ME requirements of grass silage during wk 8 to 1 prepartum. Error bars represent SEM. Least squares means of the area under the curve in CEI and HEI cows were 525 and $413 \pm 47.9 \mathrm{mmol} / \mathrm{L} \times 240$ min for glucose, 10,064 and $17,762 \pm 3,520 \mu \mathrm{IU} / \mathrm{mL} \times 240 \mathrm{~min}$ for insulin, and -20.0 and $-13.4 \pm 4.3 \mathrm{mmol} / \mathrm{L} \times 240 \mathrm{~min}$ for NEFA (n $=16)$, respectively. Concentration at time point -5 min represents the average concentration at 10 and 5 min before intravenous glucose tolerance test.

Figure 8. Treatment effects on plasma (A) glucose, (B) insulin, and $(\mathrm{C})$ nonesterified fatty acid (NEFA) concentration during intravenous glucose tolerance tests $(0.25 \mathrm{~g}$ of glucose i.v. $/ \mathrm{kg}$ of $\mathrm{BW})$ performed $9 \pm 1 \mathrm{~d}$ after parturition in dairy cows fed 2 levels of energy in the dry period: CEI $(\Delta)=108 \%$ of the ME requirements of grass silage, wheat straw, and rapeseed meal $(55 / 45 / 5 \%)$; HEI $(\boldsymbol{\square})=141 \%$ of the ME requirements of grass silage during wk 8 to 1 prepartum. Error bars represent SEM. Least squares means of the area under the curve in CEI and HEI cows were 374 and $322 \pm 30.1 \mathrm{mmol} / \mathrm{L} \times 240$ min for glucose, 3,063 and $3,884 \pm 561 \mu \mathrm{IU} / \mathrm{mL} \times 240$ for insulin, and 35.0 and $18.7 \pm 17.3 \mathrm{mmol} / \mathrm{L} \times 240 \mathrm{~min}$ for NEFA $(\mathrm{n}=16)$, respectively. Concentration at time point -5 min represents the average concentration at 10 and 5 min before intravenous glucose tolerance test. 


\section{Production Responses}

The milk yield was moderately affected by prepartal feeding, as we observed greater milk yield in HEI cows than in CEI cows from wk 4 onward. Earlier studies comparing GS and a mixture of GS and straw prepartum reported increased milk yield with GS (Dewhurst et al., 2000; McNamara et al., 2003; Ryan et al., 2003). However, those studies showed that the greatest influence on milk production performance was observed during the early weeks after calving. This probably resulted from improved BCS at calving on GS because the initial BCS at the beginning of the dry period feeding was below 2.75 (McNamara et al., 2003; Ryan et al., 2003). An temporal effect on milk yield identical to the current one was found in our previous experiment (T. Kokkonen, S. Salin, S. Jaakkola, J. Taponen, K. Elo, and A. Vanhatalo, unpublished data) conducted at the same institute with genetically similar animals from the same herd, fed with different amounts of GS during the dry period. However, as opposed to current results, the cows on the controlled-energy diet tended to produce more milk in the earlier study (T. Kokkonen, S. Salin, S. Jaakkola, J. Taponen, K. Elo, and A. Vanhatalo, unpublished data). A common element of these 2 studies was a slightly lower intake of concentrates during early lactation in animals producing less milk after the first month. In the present study, it seems that a large proportion of straw in the dry-period diet or the short concentrate feeding period, or both, had a negative effect on adaptation of the rumen to postcalving diets and subsequent production responses, as discussed earlier in this paper. With a moderately digestible GS, there is no need to dilute the feed composition by adding straw, as this dry-period feeding practice had moderately negative carryover effects on postpartal concentrate intake and, consequently, on early-lactation performance in multiparous cows of good body condition at calving. The lack of treatment effects on milk fat and protein contents is in line with earlier experiments on GS-based diets (Agenäs et al., 2003; T. Kokkonen, S. Salin, S. Jaakkola, J. Taponen, K. Elo, and A. Vanhatalo, unpublished data), reflecting the absence of any obvious differences in EB and lipid mobilization during early lactation. This also indicates that cows in early lactation have a potential to compensate for changes in prepartal nutrient intake provided that the cows receive a standard lactation ration of high quality (Agenäs et al., 2003).

\section{IVGTT}

The observed greater insulin response of HEI cows before calving (greater $\mathrm{AUC}$ of insulin and $\mathrm{AIR}_{\mathrm{G}}$ ) and the subsequent smaller AUC of glucose suggest that glucose tolerance of HEI cows was preserved before parturition. However, any environmental change in insulin sensitivity (e.g., in response to obesity) will be compensated by an increase in insulin secretion in response to glucose (Bergman, 1989; Kahn et al., 1993). Given the former, we may speculate that the greater insulin secretion in HEI cows was a compensatory mechanism in response to reduced insulin sensitivity of the peripheral tissues to preserve glucose tolerance. Salin et al. (2017) found no effect of higher energy intake on insulin response when comparing different GS allowances during the dry period. Similarly, overfeeding energy in the close-up dry period alone or during the entire dry period did not affect insulin response during IVGTT in cows on TMR based on maize silage plus WS (Schoenberg et al., 2012; Mann et al., 2016). In contrast, Jaakson et al. (2018) reported higher insulin response to IVGTT at $-21 \mathrm{~d}$ in cows with BCS $>3.75$ (1-5 scale) compared with thin cows (BCS <3.0) on GS- and hay-based TMR. However, as opposed to current results, the overconditioned cows had larger glucose AUC than the thinner cows, indicating a higher degree of IR. The discrepancies between studies may stem from different timing of the challenges, differences in feed composition and breed, and dissimilarities in initial and achieved BCS between treatments.

In agreement with Salin et al. (2017) reporting attenuated NEFA response of overfed cows during the prepartal IVGTT and enhanced sensitivity of AT after parturition, we found indications of dietary effects on insulin's action on inhibition of lipolysis on GS-based diets. However, the effects in this study were evident only before parturition, as the HEI cows needed greater insulin concentrations to elicit a similar NEFA response than the CEI cows in prepartal IVGTT. The former may reflect reduced AT sensitivity to insulin in response to overfeeding. The greater latency of NEFA response during the prepartal IVGTT in HEI cows than in CEI cows reinforces the suggestion that insulin sensitivity in AT of HEI cows was affected by dry-period energy intake. The latency is thought to result from the time it takes for the challenge to trigger the suppression of lipolysis (Boston and Moate, 2008). The extended latency period of HEI cows in prepartal IVGTT, together with the higher insulin response and a similar eventual NEFA suppression, may insinuate that the antilipolytic action of insulin was compromised in cows with higher BW gain during the dry period. Similarly, cows that lost high levels of BW had more refractory AT to insulin both pre and postpartum (Zachut et al., 2013). In contrast, Mann et al. (2016) did not find any effect of different energy intake on NEFA response during the transition period; neither did Marett et al. (2015) dur- 
ing different stages of lactation. Insulin response of the glucose metabolism, but not that of fatty acid metabolism, was negatively associated with excessive accumulation of AT in late-pregnant dairy cows as assessed by hyperinsulinemic euglygemic clamp test, whereas insulin sensitivity in AT of overconditioned cows with greater adipocytes was preserved in vitro (De Koster et al., 2015, 2016b). Recently, glucose transporter 4 protein synthesis in AT of overconditioned cows was reduced, suggesting a more severe IR prepartum, whereas no differences in insulin signaling potential were found relative to thinner cows (Jaakson et al., 2018).

We showed that basal NEFA had a strong correlation with NEFA decrement and NEFA AUC during IVGTT both pre- and postpartum. Analogous results have been reported in studies in which insulin sensitivity was assessed by different methods (Patton et al., 2009; Schoenberg et al., 2012; De Koster et al., 2015; Salin et al., 2017). The results may imply that the NEFA decrement during stimulated conditions not only is a result of the direct insulin response (the insulin AUC) after a glucose bolus but also is partially mediated by the secondary effect of insulin and lipolytic agents on basal lipolysis before IVGTT. Indeed, increased fatness of dairy cows amplified the lipolytic response of AT to catecholamine stimulation (Kokkonen et al., 2005), especially in the dry period (Theilgaard et al., 2002). Similarly, both the basal and stimulated in vitro AT sensitivity to lipolytic agents were greater in overconditioned cows than in normal-conditioned cows before parturition (De Koster et al., 2016b). Furthermore, in humans at least, the inhibitory action of insulin on AT lipolysis is dependent on the prevailing lipolytic activity, such that the antilipolytic effect of the hormone is more pronounced when the rate of lipolysis is augmented, probably due to increased insulin receptor and signal transduction activity (Zierath et al., 1998). Finally, the shutdown of lipolysis during the IVGTT challenge of ruminants may be partly directly regulated by glucose, which is the metabolic driver of the degree of NEFA suppression in human AT cells (Arner et al., 1983; Qvisth et al., 2004).

Although it was not our main intention to compare insulin responsiveness and sensitivity of tissues at different time points in the current study, we found that MM-derived values of SI and DI for the IVGTT at $-13 \mathrm{~d}$ were numerically smaller than those at $+9 \mathrm{~d}$. When the relationship of SI and $\mathrm{AIR}_{\mathrm{G}}(=\mathrm{DI})$ is visualized as shown in Figure 9, the left and upward shift of the DI values in HEI at -13 d relative to parturition underpins that the compensatory insulin secretion to match the decrease in insulin sensitivity was sufficient. However, as the DI reflects the ability of the $\beta$-cells of the pancreatic islets to compensate for IR (Bergman,
1989), the very low prepartal values of DI point to an insulin-insensitive pancreas in response to glucose and to an overall lower compensation for decreased insulin sensitivity in all animals indicated also by very low SI values, in agreement with earlier studies (Stanley, 2005; De Koster et al., 2016a; Salin et al., 2017). Further, compared with postpartal values across the treatments, the transformation of the values to the right indicates that as the value of SI is greater after parturition, there is no need for an additional compensation in insulin secretion indicated by lower DI and $\mathrm{AIR}_{\mathrm{G}}$ after parturition, in agreement with Salin et al. (2017). Indications of improvement in overall sensitivity of tissues to insulin in early lactation have been published based on different determination methods of IR (Stanley, 2005; Oliveira et al., 2016). Opposing results suggest that peripheral insulin sensitivity of dairy cows is not profoundly changed during the transition period regardless of prepartal feeding and degree of body fat mobilization (De Koster et al., 2016b; Mann et al., 2016; Weber et al., 2016). Varied results from a range of different methods of studying IR in cows in late pregnancy and early lactation clearly highlight the challenges in investigation of the transition-period metabolism (Marett et al., 2015; De Koster et al., 2017). Additional research is needed to elicit a consensus on the applicability of the MM in periparturient dairy cows.

Overall, as our previous experiment showed, when the dry period was relatively short and the oversupply of energy on GS-based diets was gradually decreased in the close-up dry period, the effects of overfeeding on whole-body insulin sensitivity were evident only in the level of AT (Salin et al., 2017). By contrast, GS fed ad libitum for a longer period of $8 \mathrm{wk}$, as in the present study, generating a more positive EB in dry cows, induced a delayed response to insulin in AT and increased insulin secretion in response to IVGTT near parturition. This, in turn, accelerated plasma glucose disappearance and inhibited glucose output or both, preserving peripheral glucose tolerance. Both the difference in energy intake and the greater potential of GS to supply glucogenic precursors in comparison with the mixture of GS and WS contributed to the observed effects on glucose and NEFA dynamics orchestrated via insulin.

\section{CONCLUSIONS}

Overfeeding energy in a GS-based diet resulted in elevated BW and BCS gain during the dry period. However, given the average difference of $40 \%$ in prepartal energy intake between the treatments, we observed differences in BW gain during the dry period that 


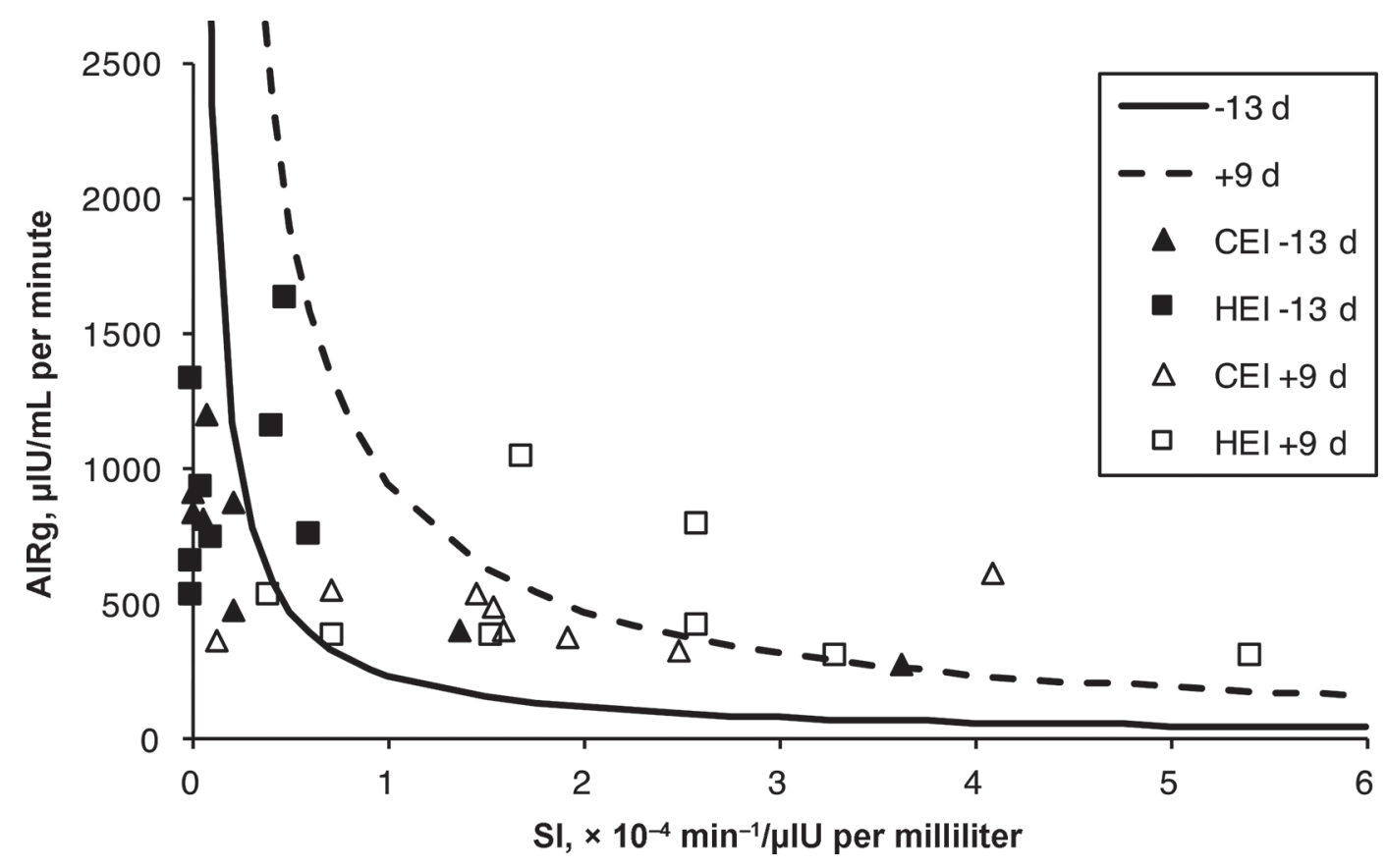

Figure 9. The hyperbolic relationship between the minimal model-derived indices of acute insulin secretion $\left(\mathrm{AIR}_{\mathrm{G}}\right)$ and insulin sensitivity index (SI) denoted as disposition index (DI) during the intravenous glucose tolerance tests $(0.25 \mathrm{~g}$ of glucose i.v. $/ \mathrm{kg}$ of BW) performed $13 \pm 5$ $\mathrm{d}$ before and $9 \pm 1 \mathrm{~d}$ after parturition in dairy cows fed 2 levels of energy in the dry period: CEI $(\Delta)=108 \%$ of the ME requirements of grass silage, wheat straw, and rapeseed meal $(55 / 45 / 5 \%)$; HEI $(\boldsymbol{\square})=141 \%$ of the ME requirements of grass silage during wk 8 to 1 prepartum. The hyperbolas were generated from extrapolated values of insulin secretion $\left(\operatorname{AIR}_{\mathrm{G}}\right)$ based on the average of observed values of DI for $-13 \mathrm{~d}(\mathrm{n}=16)$ and $+9 \mathrm{~d}(\mathrm{n}=16)$ and varying SI in the range from 0.01 to 6 (Stefanovski et al., 2011). All observations of SI and AIR $\mathrm{G}_{\mathrm{G}}$ and the corresponding hyperbolas before and after parturition are represented by the symbols defined in the figure.

were smaller than expected. Contrary to the hypothesis, high energy intake during the dry period did not affect mobilization of body reserves and feed intake after calving, whereas milk yield was greater from wk 5 onward in overfed cows. Parameters from prepartal IVGTT indicated that overfed cows had more pronounced insulin response to glucose load and a smaller glucose AUC, reflecting preserved glucose tolerance. Further, the delayed NEFA response during prepartal IVGTT suggests attenuated inhibition of lipolysis in response to oversupply of energy. The dietary differences in propionic acid availability leading to lower prepartal glucose and insulin levels in TMR-fed cows most likely contributed to the observed responses during the IVGTT prepartum. These effects of prepartal feeding on insulin sensitivity did not carry over to early lactation. Our results suggest that controlling energy intake of dry cows by dilution of moderately digestible GS by straw is not beneficial for optimally conditioned cows. In conclusion, ad libitum feeding of moderately digestible GS during the dry period had only transient effects on metabolic adaptation and insulin sensitivity during the transition period. This feeding regimen was more favorable to early-lactation performance than ad libitum-fed TMR of GS diluted with WS.

\section{ACKNOWLEDGMENTS}

The authors gratefully acknowledge the assistance of Juha Suomi and the staff at the research farm of the University of Helsinki (Helsinki, Finland) for their care of experimental animals and the assistance of the laboratory staff of the Department of Agricultural Sciences, University of Helsinki. We also extend our gratitude to Rashid Safari (University of Tabriz, Iran) for the assistance in handling the data. This study was funded by the Finnish Ministry of Agriculture and Forestry. Raisio plc Research Foundation (Raisio, Finland) and the Agricultural Research Foundation of August Johannes and Aino Tiura (Espoo, Finland) supported the first author financially.

\section{REFERENCES}

Agenäs, S., E. Burstedt, and K. Holtenius. 2003. Effects of feeding intensity during the dry period. 1. Feed intake, body weight, and milk production. J. Dairy Sci. 86:870-882.

Arner, P.., J. Bolinder, and J. Ostman. 1983. Glucose stimulation of the antilipolytic effect of insulin in humans. Science 220:1057-1059.

Aschenbach, J. R., N. B. Kristensen, S. S. Donkin, H. M. Hammon, and G. B. Penner. 2010. Gluconeogenesis in dairy cows: The secret of making sweet milk from sour dough. IUBMB Life 62:869-877.

Bergman, R. N. 1989. Toward physiological understanding of glucose tolerance. Minimal-model approach. Diabetes 38:1512-1527. 
Boston, R. C., and P. J. Moate. 2008. A novel minimal model to describe NEFA kinetics following an intravenous glucose challenge. Am. J. Physiol. Regul. Integr. Comp. Physiol. 294:R1140-R1147.

Boston, R. C., D. Stefanovski, P. J. Moate, A. E. Sumner, R. M. Watanabe, and R. N. Bergman. 2003. MINMOD Millennium: A computer program to calculate glucose effectiveness and insulin sensitivity from the frequently sampled intravenous glucose tolerance test. Diabetes Technol. Ther. 5:1003-1015.

Butler, M., J. Patton, J. J. Murphy, and F. J. Mulligan. 2011. Evaluation of a high-fibre total mixed ration as a dry cow feeding strategy for spring-calving Holstein Friesian dairy cows. Livest. Sci. 136:85-92.

Dann, H. M., N. B. Litherland, J. P. Underwood, M. Bionaz, A. D'Angelo, J. W. McFadden, and J. K. Drackley. 2006. Diets during far-off and close-up dry periods affect periparturient metabolism and lactation in multiparous cows. J. Dairy Sci. 89:3563-3577.

De Koster, J., M. Hostens, K. Hermans, W. Van den Broeck, and G. Opsomer. 2016a. Validation of different measures of insulin sensitivity of glucose metabolism in dairy cows using the hyperinsulinemic euglycemic clamp test as the gold standard. Domest. Anim. Endocrinol. 57:117-126.

De Koster, J., M. Hostens, M. Van Eetvelde, K. Hermans, S. Moerman, H. Bogaert, E. Depreester, B. Van, and G. Opsomer. 2015. Insulin response of the glucose and fatty acid metabolism in dry dairy cows across a range of body condition scores. J. Dairy Sci. 98:4580-4592.

De Koster, J., W. Van den Broeck, L. Hulpio, E. Claeys, M. Van Eetvelde, K. Hermans, M. Hostens, V. Fievez, and G. Opsomer. 2016b. Influence of adipocyte size and adipose depot on the in vitro lipolytic activity and insulin sensitivity of adipose tissue in dairy cows at the end of the dry period. J. Dairy Sci. 99:2319-2328.

De Koster, J., M. Van Eetvelde, K. Hermans, W. Van den Broeck, M. Hostens, and G. Opsomer. 2017. Short communication: Limitations of glucose tolerance tests in the assessment of peripheral tissue insulin sensitivity during pregnancy and lactation in dairy heifers. J. Dairy Sci. 100:2381-2387.

Dewhurst, R. J., D. W. R. Davies, and W. J. Fisher. 2010. Effects of forage NDF content and body condition score on forage intake by Holstein-Friesian dairy cows in the dry period. Animal 4:76-80.

Dewhurst, R. J., J. M. Moorby, M. S. Dhanoa, R. T. Evans, and W. J. Fisher. 2000. Effects of altering energy and protein supply to dairy cows during the dry period. 1. Intake, body condition, and milk production. J. Dairy Sci. 83:1782-1794.

Dirksen, G. U., H. G. Liebich, and E. Mayer. 1985. Adaptive changes of the ruminal mucosa and their functional and clinical significance. Bov. Pract. 20:116-120.

Douglas, G. N., T. R. Overton, H. G. Bateman II, H. M. Dann, and J. K. Drackley. 2006. Prepartal plane of nutrition, regardless of dietary energy source, affects periparturient metabolism and dry matter intake in Holstein cows. J. Dairy Sci. 89:2141-2157.

Drackley, J. K., and F. C. Cardoso. 2014. Prepartum and postpartum nutritional management to optimize fertility in high-yielding dairy cows in confined TMR systems. Animal 8:5-14

Drackley, J. K., R. L. Wallace, D. Graugnard, J. Vasquez, B. F. Richards, and J. J. Loor. 2014. Visceral adipose tissue mass in nonlactating dairy cows fed diets differing in energy density. J. Dairy Sci. 97:3420-3430.

Edmonson, A. J., I. J. Lean, L. D. Weaver, T. Farver, and G. Webster. 1989. A body condition scoring chart for Holstein dairy cows. J. Dairy Sci. 72:68-78.

Foster, K. J., K. G. Alberti, L. Hinks, B. Lloyd, A. Postle, P. Smythe, D. C. Turnell, and R. Walton. 1978. Blood intermediary metabolite and insulin concentrations after an overnight fast: Reference ranges for adults, and interrelations. Clin. Chem. 24:1568-1572.

Friggens, N. C., J. B. Andersen, T. Larsen, O. Aaes, and R. J. Dewhurst. 2004. Priming the dairy cow for lactation: A review of dry cow feeding strategies. Anim. Res. 53:453-473.

Goodlad, R. A. 1981. Some effects of diet on the mitotic index and the cell cycle of the ruminal epithelium of sheep. Q. J. Exp. Physiol. 66:487-499.
Holtenius, K., S. Agenäs, C. Delavaud, and Y. Chilliard. 2003. Effects of feeding intensity during the dry period. 2. Metabolic and hormonal responses. J. Dairy Sci. 86:883-891.

Huida, L., H. Väätäinen, and M. Lampila. 1986. Comparison of dry matter contents in grass silages as determined by oven drying and gas chromatographic water analysis. Annales Agriculturae Fenniae. 25:215-230.

Jaakson, H., P. Karis, K. Ling, A. Ilves-Luht, J. Samarütel, M. Henno, I. Jõudu, A. Waldmann, E. Reimann, P. Pärn, R. M. Bruckmaier, J. J. Gross, T. Kaart, M. Kass, and M. Ots. 2018. Adipose tissue insulin receptor and glucose transporter 4 expression, and blood glucose and insulin responses during glucose tolerance tests in transition Holstein cows with different body condition. J. Dairy Sci. 101:752-766.

Janovick, N. A., Y. R. Boisclair, and J. K. Drackley. 2011. Prepartum dietary energy intake affects metabolism and health during the periparturient period in primiparous and multiparous Holstein cows. J. Dairy Sci. 94:1385-1400.

Janovick, N. A., and J. K. Drackley. 2010. Prepartum dietary management of energy intake affects postpartum intake and lactation performance by primiparous and multiparous Holstein cows. J. Dairy Sci. 93:3086-3102.

Kahn, S. E., R. L. Prigeon, D. K. McCulloch, E. J. Boyko, R. N. Bergman, M. W. Schwartz, J. L. Neifing, W. K. Ward, J. C. Beard, and J. P. Palmer. 1993. Quantification of the relationship between insulin sensitivity and B-cell function in human subjects: Evidence for a hyperbolic function. Diabetes 42:1663-1672.

Kokkonen, T., J. Taponen, T. Anttila, L. Syrjälä-Qvist, C. Delavaud, Y. Chilliard, M. Tuori, and A. T. Tesfa. 2005. Effect of body fatness and glucogenic supplement on lipid and protein mobilization and plasma leptin in dairy cows. J. Dairy Sci. 88:1127-1141.

Kokkonen, T., and A. Vanhatalo. 2014. A meta-analysis of the effects of dry period energy intake on retention and mobilization of body tissue, and lactation performance of dairy cows. Proc. Aust. Soc. Anim. Prod. 30:288.

Lamminen, M., A. Halmemies-Beauchet-Filleau, T. Kokkonen, I. Simpura, S. Jaakkola, and A. Vanhatalo. 2017. Comparison of microalgae and rapeseed meal as supplementary protein in the grass silage based nutrition of dairy cows. Anim. Feed Sci. Technol. 234:295-311.

Little, M. W., N. E. O'Connell, M. D. Welsh, J. Barley, K. G. Meade, and C. P. Ferris. 2016. Prepartum concentrate supplementation of a diet based on medium-quality grass silage: Effects on performance, health, fertility, metabolic function, and immune function of low body condition score cows. J. Dairy Sci. 99:7102-7122.

Loor, J. J., H. M. Dann, N. A. Janovick Guretzky, R. E. Everts, R. Oliveira, C. A. Green, N. B. Litherland, S. L. Rodriguez-Zas, H. A. Lewin, and J. K. Drackley. 2006. Plane of nutrition prepartum alters hepatic gene expression and function in dairy cows as assessed by longitudinal transcript and metabolic profiling. Physiol. Genomics 27:29-41.

Luke. 2017. Finnish feed tables and feeding recommendations. Accessed Dec. 6, 2017. https://portal.mtt.fi/portal/page/portal/ Rehutaulukot/feed_tables_english.

Mandok, K. S., J. K. Kay, S. L. Greenwood, G. R. Edwards, and J. R. Roche. 2013. Requirements for zero energy balance of nonlactating, pregnant dairy cows fed fresh autumn pasture are greater than currently estimated. J. Dairy Sci. 96:4070-4076.

Mann, S., F. A. L. Yepes, M. Duplessis, J. J. Wakshlag, T. R. Overton, B. P. Cummings, and D. V. Nydam. 2016. Dry period plane of energy: Effects on glucose tolerance in transition dairy cows. J. Dairy Sci. 99:701-717.

Mann, S., F. A. L. Yepes, T. R. Overton, J. J. Wakshlag, A. L. Lock, C. M. Ryan, and D. V. Nydam. 2015. Dry period plane of energy: Effects on feed intake, energy balance, milk production, and composition in transition dairy cows. J. Dairy Sci. 98:3366-3382.

Marett, L. C., M. J. Auldist, P. J. Moate, W. J. Wales, K. L. Macmillan, F. R. Dunshea, and B. J. Leury. 2015. Response of plasma glucose, insulin, and nonesterified fatty acids to intravenous glucose tolerance tests in dairy cows during a 670-day lactation. J. Dairy Sci. 98:179-189. 
McNamara, S., F. P. O'Mara, M. Rath, and J. J. Murphy. 2003. Effects of different transition diets on dry matter intake, milk production, and milk composition in dairy cows. J. Dairy Sci. 86:2397-2408.

Odongo, N. E., O. AlZahal, M. I. Lindinger, T. F. Duffield, E. V. Valdes, S. P. Terrell, and B. W. McBride. 2006. Effects of mild heat stress and grain challenge on acid-base balance and rumen tissue histology in lambs. J. Anim. Sci. 84:447-455.

Oliveira, L. H., A. B. Nascimento, P. L. J. Monteiro Jr., M. M. Guardieiro, M. C. Wiltbank, and R. Sartori. 2016. Development of insulin resistance in dairy cows by 150 days of lactation does not alter oocyte quality in smaller follicles. J. Dairy Sci. 99:9174-9183.

Patton, J., J. J. Murphy, F. P. O'Mara, and S. T. Butler. 2009. Responses of North American and New Zealand strains of HolsteinFriesian dairy cattle to homeostatic challenges during early and mid-lactation. Animal 3:251-260.

Pires, J. A. A., C. Delavaud, Y. Faulconnier, D. Pomiès, and Y. Chilliard. 2013. Effects of body condition score at calving on indicators of fat and protein mobilization of periparturient Holstein-Friesian cows. J. Dairy Sci. 96:6423-6439.

Pires, J. A. A., A. H. Souza, and R. R. Grummer. 2007. Induction of hyperlipidemia by intravenous infusion of tallow emulsion causes insulin resistance in Holstein cows. J. Dairy Sci. 90:2735-2744.

Puhakka, L., S. Jaakkola, I. Simpura, T. Kokkonen, and A. Vanhatalo. 2016. Effects of replacing rapeseed meal with fava bean at 2 concentrate crude protein levels on feed intake, nutrient digestion, and milk production in cows fed grass silage-based diets. J. Dairy Sci. 99:7993-8006.

Qvisth, V., E. Hagström-Toft, S. Enoksson, R. S. Sherwin, S. Sjöberg, and J. Bolinder. 2004. Combined hyperinsulinemia and hyperglycemia, but not hyperinsulinemia alone, suppress human skeletal muscle lipolytic activity in vivo. J. Clin. Endocrinol. Metab. 89:4693-4700.

Rabelo, E., R. L. Rezende, S. J. Bertics, and R. R. Grummer. 2003. Effects of transition diets varying in dietary energy density on lactation performance and ruminal parameters of dairy cows. J. Dairy Sci. 86:916-925.

Roche, J. R., A. W. Bell, T. R. Overton, and J. J. Loor. 2013. Nutritional management of the transition cow in the 21st century-A paradigm shift in thinking. Anim. Prod. Sci. 53:1000-1023.

Roche, J. R., N. C. Friggens, J. K. Kay, M. W. Fisher, K. J. Stafford, and D. P. Berry. 2009. Invited review: Body condition score and its association with dairy cow productivity, health, and welfare. J. Dairy Sci. 92:5769-5801.

Roche, J. R., S. Meier, A. Heiser, M. D. Mitchell, C. G. Walker, M. A. Crookenden, M. V. Riboni, J. J. Loor, and J. K. Kay. 2015. Effects of precalving body condition score and prepartum feeding level on production, reproduction, and health parameters in pasture-based transition dairy cows. J. Dairy Sci. 98:7164-7182.

Rukkwamsuk, T., T. Wensing, and M. J. Geelen. 1998. Effect of overfeeding during the dry period on regulation of adipose tissue metabolism in dairy cows during the periparturient period. J. Dairy Sci. 81:2904-2911.

Ryan, G., J. J. Murphy, S. Crosse, and M. Rath. 2003. The effect of pre-calving diet on post-calving cow performance. Livest. Prod. Sci. 79:61-71.

Salin, S., J. Taponen, K. Elo, I. Simpura, A. Vanhatalo, R. Boston, and T. Kokkonen. 2012. Effects of abomasal infusion of tallow or camelina oil on responses to glucose and insulin in dairy cows during late pregnancy. J. Dairy Sci. 95:3812-3825.

Salin, S., A. Vanhatalo, K. Elo, J. Taponen, R. C. Boston, and T. Kokkonen. 2017. Effects of dietary energy allowance and decline in dry matter intake during the dry period on responses to glucose and insulin in transition dairy cows. J. Dairy Sci. 100:5266-5280.

Schoenberg, K. M., R. M. Ehrhardt, and T. R. Overton. 2012. Effects of plane of nutrition and feed deprivation on insulin responses in dairy cattle during late gestation. J. Dairy Sci. 95:670-682.

Selim, S., T. Kokkonen, J. Taponen, A. Vanhatalo, and K. Elo. 2015. Effect of prepartal ad libitum feeding of grass silage on transcriptional adaptations of the liver and subcutaneous adipose tissue in dairy cows during the periparturient period. J. Dairy Sci. 98:55155528 .

Selim. S., S. Salin, J. Taponen, A. Vanhatalo, T. Kokkonen, and K. T. Elo. 2014. Prepartal dietary energy alters transcriptional adaptations of the liver and subcutaneous adipose tissue of dairy cows during the transition period. Physiol. Genomics 46:328-337.

Sjaunja, L. O., L. Baevre, L. Junkkarinen, J. Pedersen, and J. Setala. 1991. A Nordic proposal for an energy corrected milk (ECM) formula. Pages 156-157 in Performance Recording of Animal State of the Art 1990. P. Gaillon, and Y. Chabert, ed. EAAP Publication 50. Center for Agricultural Publishing and Documentation, Wageningen, the Netherlands.

Stanley, C. C. 2005. Regulation of glucose metabolism in dairy cattle. $\mathrm{PhD}$ Thesis. Louisiana State University and Agricultural and Mechanical College, Baton Rouge.

Steele, M. A., J. Croom, M. Kahler, O. AlZahal, S. E. Hook, K. Plaizier, and B. W. McBride. 2011. Bovine rumen epithelium undergoes rapid structural adaptations during grain-induced subacute ruminal acidosis. Am. J. Physiol. Regul. Integr. Comp. Physiol. 300:R1515-R1523.

Stefanovski, D., J. M. Richey, O. Woolcott, M. Lottati, D. Zheng, L. N. Harrison, V. Ionut, S. P. Kim, I. Hsu, and R. N. Bergman. 2011. Consistency of the disposition index in the face of diet induced insulin resistance: Potential role of FFA. PLoS One 6:e18134.

Theilgaard, P., N. C. Friggens, K. H. Sloth, and K. L. Ingvartsen. 2002. The effect of breed, parity and body fatness on the lipolytic response of dairy cows. Anim. Sci. 75:209-219.

van der Drift, S. G. A., R. R. Everts, M. Houweling, L. A. M. G. van Leengoed, J. A. Stegeman, A. G. M. Tielens, and R. Jorritsma. 2013. Effects of $\beta$-hydroxybutyrate and isoproterenol on lipolysis in isolated adipocytes from periparturient dairy cows and cows with clinical ketosis. Res. Vet. Sci. 94:433-439.

Vickers, L. A., D. M. Weary, D. M. Veira, and M. A. von Keyserlingk. 2013. Feeding a higher forage diet prepartum decreases incidences of subclinical ketosis in transition dairy cows. J. Anim. Sci. 91:886-894.

Weber, C., C. T. Schäff, U. Kautzsch, S. Börner, S. Erdmann, S. Görs, M. Röntgen, H. Sauerwein, R. M. Bruckmaier, C. C. Metges, B. Kuhla, and H. M. Hammon. 2016. Insulin-dependent glucose metabolism in dairy cows with variable fat mobilization around calving. J. Dairy Sci. 99:6665-6679.

Zachut, M., H. Honig, S. Striem, Y. Zick, S. Boura-Halfon, and U. Moallem. 2013. Periparturient dairy cows do not exhibit hepatic insulin resistance, yet adipose-specific insulin resistance occurs in cows prone to high weight loss. J. Dairy Sci. 96:5656-5669.

Zierath, J. R., J. N. Livingston, A. Thorne, J. Bolinder, S. Reynisdottir, F. Lonnqvist, and P. Arner. 1998. Regional difference in insulin inhibition of non-esterified fatty acid release from human adipocytes: Relation to insulin receptor phosphorylation and intracellular signalling through the insulin receptor substrate-1 pathway. Diabetologia 41:1343-1354. 